Discussion Papers
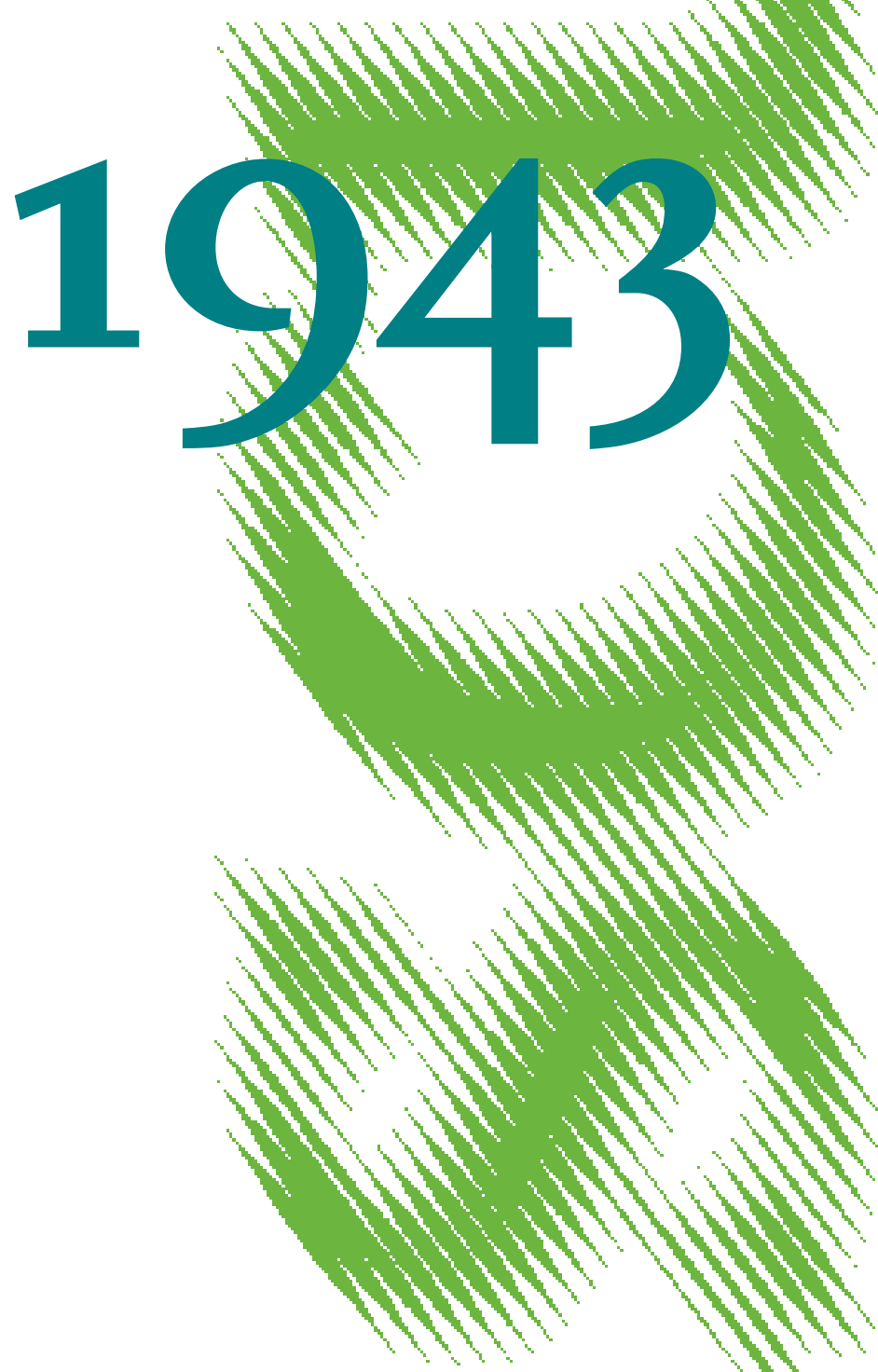

Home Bias in Sovereign Exposure and the Probability of Bank

Default - Evidence from EU Stress Test Data 
Opinions expressed in this paper are those of the author(s) and do not necessarily reflect views of the institute.

IMPRESSUM

(C) DIW Berlin, 2021

DIW Berlin

German Institute for Economic Research

Mohrenstr. 58

10117 Berlin

Tel. +49 (30) $89789-0$

Fax +49 (30) $89789-200$

http://www.diw.de

ISSN electronic edition 1619-4535

Papers can be downloaded free of charge from the DIW Berlin website:

http://www.diw.de/discussionpapers

Discussion Papers of DIW Berlin are indexed in RePEc and SSRN:

http://ideas.repec.org/s/diw/diwwpp.html

http://www.ssrn.com/link/DIW-Berlin-German-Inst-Econ-Res.html 


\title{
Home Bias in Sovereign Exposure and the Probability of Bank Default - Evidence From EU Stress Test Data
}

\author{
Dominik Meyland* Dorothea Schäfer ${ }^{\dagger}$
}

\begin{abstract}
Since the European debt crisis economists and politicians discuss intensively the sovereign-bank nexus. The high activity in sovereign bond issuance required to mitigate the burden of the Covid19 crisis will rather intensify this debate than calm it down. Surprisingly, however, we still have only limited knowledge about the impact of a home bias in sovereign exposure on bank stability. This paper provides a new way to use European stress test data to study this relationship. In addition, we explore the effect on a bank's probability of default if the existing capital requirement privilege for EU sovereign exposures were abolished. Our results support the conceptual idea behind the nexus theory. Interestingly, the effect of a home bias on bank stability is contingent on the home country's solvency. If the home country is sufficiently solvent, investments in home sovereign bonds may improve bank stability. The findings clearly support the benefits of additional CET1 capital buffers. Regulation focusing on the home bias should account for heterogeneous effects depending on the home country's solvency.
\end{abstract}

Key Words: Home Bias, Sovereign Bonds, Bank Stability, Equity Requirements, Financial Regulation

JEL codes: G21,G28,K15

\footnotetext{
*dominik.meyland@unisg.ch, University of St. Gallen

$\dagger$ dschaefer@diw.de, Germany Institute for Economic Research DIW Berlin; Jönköping International Business School, Jönköping University; and CERBE, Italy
} 


\section{Introduction}

The exposure of banks to sovereign bonds is large. Li and Zinna (2018) estimate that, between 2008 and 2015, more than one third of banks' credit risk is caused by sovereign bonds. During the Covid crisis, governments rolled out huge rescue programs for enterprises and households. Banks are the main buyers of these debt issuances. Accordingly, sovereign debt exposure increased, becoming larger than it was before.

Banks usually prefer to invest in the sovereign bonds of their home country. The home-bias directly interconnects the stability of banks and governments. The interconnection is often considered to be the key element of the European sovereign debt crisis from 2011 to 2012. So far, we know surprisingly little about the link between home-bias and individual bank stability despite its potentially far-reaching effect. This paper focuses on this research gap.

Sovereign bonds enjoy an "equity privilege" originating in the notion of government debt as being risk-free. That is, banking regulation often excludes sovereign exposure from capital requirements. The privilege also exists for EU sovereign bonds (Article 114 CRR, European Union, 2013). Accordingly, the banks' risk buffers for exposure to EU member states are uniformly zero. However, it became clear when the European debt crisis began - if not before - that the idea of risk-free sovereign debt fails to match reality. An intense, still ongoing, debate started about how to treat sovereign bonds in the Basel framework (BCBS, 2017b). The goal of curbing the banks' home bias is at the center of this discussion. Implicitly, most protagonists assume that the home-bias in the sovereign debt exposure deteriorates bank stability. However, thorough analyses of the issue are rare. We use the EBA stress test data to address this research gap. The stress tests only include banks which meet the defined size threshold. Accordingly, banks participating in the stress test are fairly large banks. The home-bias enfolds a direct effect on bank stability by linking the solvency of banks to the solvency of the home country. In addition, it exerts an indirect effect as the equity privilege for sovereign exposure causes the absence of risk buffers for this exposure. To disentangle the direct effect of the home bias from the indirect effect, we study scenarios in which banks are assumed to own the required additional risk buffers.

We propose a new methodology to account for the bank's potential equity requirements from sovereign exposure. Specifically, we use the risk differential approach of Yawitz (1977) to calibrate the countries' probability of default with available stress test data, then we apply the results to the well-known capital requirements formula of the Internal Risk Based Approach of the Basel framework (BCBS, 2006). The results enable us to calculate the banks' potential equity requirements due to sovereign exposure. Thus, the applied logit model yields the probability of bank default as a function of both the home 
bias and the potentially required CET1 capital buffers.

The findings suggest that a home bias increases the bank's default probability only if the solvency of the home sovereign is fairly low. In general, exposure to the own sovereign has a stabilizing impact. Moreover, the results reveal the stabilizing impact of CET1 capital as well as of high returns and a bank size above the average. Accordingly, abolishing the capital privilege or introducing generally higher CET1 capital buffers may reduce the linkage between sovereign bonds and banks' default probability.

We complement previous research analyzing the drivers of the home bias in banks' balance sheets, especially Andreeva and Vlassopoulos (2019), Altavilla, Pagano, and Simonelli (2017), Horváth, Huizinga, and Ioannidou (2015) and Acharya and Steffen (2015). In addition, we add novel evidence on the impact of the home bias on bank stability that goes well beyond Schnabel and Schüwer (2016), which studies how the home bias in sovereign bonds affects the spreads of a bank's Credit Default Swap (CDS).

The paper is structured in the following way. In Section 2 we explain the sovereignbanking nexus and review the related literature. Section 3 calculates a country's default probability based on sovereign bond yields and derives the respective capital requirements for the bonds. Section 4 presents data and estimation models. In Section 5, we discuss the results, while Section 6 concludes.

\section{Theoretical Background and Literature Review}

Most banks lend to their home country or hold home sovereign bonds. The lending causes a direct linkage between the banking sector and the government, which is often called the "sovereign-banking nexus." Figure 1 illustrates the nexus.

[Figure 1]

Generally, banks finance their activities with equity and debt including customers' deposits. The equity (bank capital) works as a risk buffer such that the debt and deposit holders should not be affected when losses occur. A deterioration of the market value of a bank's assets cuts into its capital buffer. Subsequently, the distance to default, that is the capital buffer in excess of the minimum Basel capital threshold, shrinks. Issuing new equity may be too costly. Thus, the bank may respond to the decrease in equity capital with less lending and a shortening of its asset side. Due to the worsened access to bank borrowing, the economy may suffer, growth may decline, and tax income may drop. More losses would reduce the bank's risk buffer even further and increase the probability of default. Risks would pile up in the banking system if the interbank connections are close. If one bank is hit by a shock, e.g., a default or a reduction of the perceived solvency, contagion will harm other financial institutions and threaten the stability of the whole system. 
To avoid a chain reaction within the system governments may bailout the ailing bank(s). During the Global Financial Crisis (GFC), governments around the world responded to reduced market values of bank assets in this way. Crotty (2009) describes a massive decline of the market value of mortgages in the US as the starting point of the GFC. The US government was forced to develop the Troubled Asset Relief Program (TARP), under which the US government provided liquidity to several systemically relevant financial institutions. European governments undertook other bail-out operations in response to the turmoil in their banking systems. Rescue operations for the banking system are expensive for the home sovereign. As a result, the sovereign debt burden goes up, often followed by a deterioration of the sovereign rating and a decline of the value of home government bonds in the banks' books.

Brunnermeier et al. (2016) propose two feedback loops linking the riskiness of banks and sovereigns (Figure 1). They start from a home bias in banks' sovereign exposure. A decrease of the creditworthiness of the government reduces the market value of that exposure. The feedback of the banking sector affects the riskiness of the government debt due to its negative effect on the economic conditions in the country and an increasing risk of costly bailouts.

The general explanation for the existence of the home bias in investors' strategies is information asymmetry. However, studies specifically analyzing bank investment behavior in Europe during the Great Financial Crisis (GFC) propose other motives. Acharya and Steffen (2015) argue that European banks assumed a convergence between the yields of Germany with Greece, Ireland, Portugal, Spain and Italy after the increase of the spread between the yields of these countries. As a result, bank investments in sovereign bonds issued by peripheral European Union countries increased between 2009 and 2012. In particular, banks in vulnerable countries accumulated a home bias in their sovereign debt portfolio. The findings suggest that banks deliberately link their own fate to that of their home governments.

Horváth et al. (2015) study which bank characteristics drive the European banks' overweighting of domestic sovereign bonds. They reveal that large banks hold substantially more domestic sovereign bonds than smaller banks. The same applies for banks that are state-owned. Horváth et al. (2015) also analyze effects of external liquidity injections in the European banking system implemented by the ECB through Long Term Refinancing Operations (LTRO). The evidence indicates that banks in vulnerable EU member states used the additional capital for investments in home sovereign bonds and increased their home bias. Moreover, they find that banks with risky portfolios, meaning with high leverage, tend to hold more domestic sovereign bonds than other banks if the credit default 
swap (CDS) of their home country indicates a higher risk of these bonds. ${ }^{1}$ The observed risk seeking behavior of these banks is in line with the well-known risk shifting theory of Jensen and Meckling (1976), stating that equity-holders can transfer wealth from bondholders by engaging in risky projects. In this case, banks invest in risky bonds issued by vulnerable EU countries to obtain a higher return than with risk-free investments e.g. German bonds. As long as the government is able to service its debt, the bank's equityholder benefits from the higher return as the bondholder's interests are constant. However, if the government declares bankruptcy, the bank will soon follow. Risk-shifting can be beneficial for the equity-holders if the value of the bank is low and, therefore, a potential loss due to bankruptcy and liquidation of the bank is smaller than potential profits caused by the risky investments. Accordingly, risk shifting in the form of a home bias can be interpreted as strategy that maximizes the profit of the bank's equity-holder but increases the bank's overall probability of default.

Andreeva and Vlassopoulos (2019) study the risk shifting behavior of European banks during the European debt crisis. Based on a theoretical model, they empirically analyze how domestic banks' bond purchases are affected by the interaction of sovereign bond's risk with the sovereign-bank nexus. The findings show that banks over-weight investments in domestic sovereign bonds when the bonds are very risky and when a close nexus exists in a country. The results can be interpreted as an indication of risk shifting behavior by banks in countries with high default risk.

Altavilla et al. (2017) show that European banks with low regulatory capital overweigh investments in risky European sovereign bonds. The reason for this could be that there are no capital requirements for investments in European government bonds compared to other bonds. Moreover, the banks can use the sovereign bonds, eligible as collateral for the ECB, to refinance their operations. This financing option is important for banks, especially in times of crisis when no viable alternatives exist providing liquidity. In this case, the central bank acts as the lender of last resort (LOLR) to prevent a financial crisis due to insufficient funds in the banking sector. ${ }^{2}$

Uhlig (2014) provides a model to analyze the relationship between a central bank of a monetary union, the governments that are also the financial regulating authorities, and the banking sectors of this union. In this model, countries with high default risk have an incentive to allow their banks to hold large amounts of domestic sovereign bonds to benefit from banks' opportunity to use the bonds as collateral. Consequently, a home bias

\footnotetext{
${ }^{1} \mathrm{~A}$ CDS is a credit default insurance. The issuer of a CDS receives a payment from the counterpart if the underlying credit defaults but must pay an upfront and regular payment. The upfront payment of a $\mathrm{CDS}$, the price of the insurance, can be used to derive the default risk of the credit. Generally, a higher price indicates a higher default risk. An introduction to the theory of CDS is provided by Hull (2017).

${ }^{2}$ The lender of last resort theory goes back to Thornton (1802). A well-structured literature review is found in Freixas, Giannini, Hoggarth, and Soussa (2000).
} 
may arise. In sum, the existing research finds that European banks have an incentive to, and indeed do, build up large home sovereign debt exposures on their balance sheets.

Only a few studies analyze the impact of the home bias on financial stability and the risk of bailouts in the financial system. Acharya, Drechsler, and Schnabl (2014) develop a model that analyzes the linkages between bank bailouts and the sovereign credit risk. In their model, the governments bailout the financial sector to improve the financial services supply in the economy and to boost output, e.g., in a recession. To do so, the government issues new bonds. However, as future output and the related tax income is uncertain, an additional adverse output shock may increase the risk of default in the financial sector, while a reduced credit worthiness of the government negatively influences future bailout capacities. Acharya et al. (2014) confirm that the possibility of a co-movement of sovereign risk and bank risk is real, as described in the Figure 1 (bailout feedback).

Schnabel and Schüwer (2016) analyze the effects of the banks' home bias on their default risk. The default risk is approximated with the corresponding CDS premium. Their findings indicate a negative association between the individual banks' sovereign home bias and bank stability. However, as emphasized by Schnabel and Schüwer (2016), the results do not necessarily show a causal effect of the home bias because the starting point could also be the risk shifting behavior. A banks' shareholders may simply use the existing CDS premium as an indicator for the own default probability and decide whether higher risk-taking is beneficial. In this case, banks with high default probabilities would buy risky assets, such as domestic sovereign bonds, that would harm stability. Accordingly, the causal direction would be reverse. We strike a different path to circumvent Schnabel and Schüwer (2016)'s reverse causality problem in our study. Specifically, we use the prospective solvency calculated from stress test data as dependent variable and regress this indicator on the current individual banks' home bias.

\section{Conceptional Framework}

\subsection{Calibration of the Home Bias}

A very simple indicator for the home bias is the ratio between the home sovereign bond exposure and all sovereign bonds held by the bank. However, this definition has a major drawback. From the perspective of portfolio theory, a bank should invest in a welldiversified sovereign bond portfolio. A simple ratio definition would lead to a home bias of zero if the bank does not invest in home sovereign bonds. However, this results in a non-optimal return risk profile of the portfolio, which ideally should be composed out of all existing sovereign bonds in the world. According to portfolio theory, an indicator 
variable for the home bias should evaluate the banks' home investments relative to an unbiased portfolio including foreign as well as domestic sovereign bonds. Therefore, existing research usually defines the home bias as the ratio between home sovereign bonds and total sovereign bonds held by the bank relative to an unbiased reference portfolio.

Horváth et al. (2015) apply an adjusted definition developed by French and Poterba (1991), which was originally used for the analysis of the home bias in equity investments. Conceptually, this definition compares the ratio between home sovereign bonds and total sovereign bonds in banks' portfolios with the ratio between the total outstanding amount of home sovereign bonds and all existing sovereign bonds in the world. Hence, the reference portfolio is composed according to the shares of governments' debt in total debt. The disadvantage of this indicator is that banks based in a country with a lot of outstanding debt relative to GDP could hold a higher proportion of bonds issued by their home government than banks in countries with less outstanding debt. In an extreme case, banks based in the one country that issued the most sovereign bonds worldwide could hold only home sovereign bonds but have a low home bias. However, a higher debt share may be associated, ceteris paribus, with a higher default probability of this country. Accordingly, we consider this definition inappropriate for the analysis of the impact of banks' home sovereign exposure on bank stability.

Instead, inspired by Schnabel and Schüwer (2016), we construct the reference portfolio based on countries' GDP shares and define

$$
\text { Home Bias }=\frac{\frac{S_{0 v_{H o m e}}}{S o v_{E U}}}{\frac{G D P_{H o m e}}{G D P_{E U}}} .
$$

Sov $_{\text {Home }}$ is the share of home sovereign bonds in the bank's EU sovereign bond exposure $S o v_{E U}$, and $\frac{G D P_{H o m e}}{G D P_{E U}}$ is the home country's GDP share in total GDP of the European Union. The value of the home bias, as defined in equation (1), ranges from zero to $\infty$. A bank would overweight the home sovereign exposure in its portfolio when Home Bias $>1$ and underweight it if $0 \leq$ Home Bias $<1$. A value of Home Bias $=1$ indicates that the bank has a fully diversified and balanced EU sovereign portfolio.

\subsection{Calibration of the Equity Requirements for Sovereign Exposure}

The banking sector is highly regulated because of its associated risks and the importance of banks for the economy. To keep risk at bay, the Basel Committee on Banking Supervision (BCBS) launched three accords: Basel I (1988), Basel II (2004), and Basel (2010); the latter coming in response to the Global Financial Crisis (GFC). The proposed minimum capital requirements for banks are the center piece of these accords. The Basel accord's minimum capital requirement are based on risk-weighted assets, $R W A=R W \times$ 
Exposure. The bank's capital requirement (equity) is defined as

$$
\text { Equity }=0.08 \times \mathrm{RW} \times \text { Exposure }=0.08 \times \mathrm{RWA}
$$

Banks have different opportunities to determine the risk of their asset side (BCBS, 2006). Either they use the standard approach allocating pre-determined risk weights to the exposure according to rating figures (BCBS, 2006) or they apply the internal rating-based approach (IRB). The IRB approach allows banks to assess the exposure's probability of default $(P D)$ with own models. The $P D$ is defined as the probability of a standardized normally distributed return $Y$ to fall below the contracted return of the bond $C$, $P(Y<C)=P D$. The share of required equity is calibrated as

$$
K=\left[L G D \mathcal{N}\left[\frac{\mathcal{G}(P D)}{\sqrt{1-R}}+\sqrt{\frac{R}{1-R}} \mathcal{G}(0.999)\right]-P D L G D\right] \frac{(1+(M-2.5) b)}{1-1.5 b}
$$

The calibration of $K$ is based on a $99.9 \%$ value at risk approach assuming normally distributed returns. The $L G D$ describes the percentage of a credit exposure that will be lost in the case of default. $\mathcal{N}$ denotes the cumulative normal distribution of a random variable and $\mathcal{G}$ is its inverse function. The variable $M$ measures the maturity of the exposure and is $M=2.5$ within the basic IRB approach. ${ }^{3}$

$$
\begin{aligned}
R & =0.12 \frac{\left(1-e^{-50 P D}\right)}{\left(1-e^{-50}\right)}+0.24\left(1-\frac{\left(1-e^{-50 P D}\right)}{\left(1-e^{-50}\right)}\right) \text { and } \\
b & =[0.11852-0.05478 \ln (P D)]^{2}
\end{aligned}
$$

capture diversification effects arising from correlations between different debtors and an adjustment for the maturity of the credit, respectively. ${ }^{4}$ With a maturity of 2.5 and an $L G D=45 \%,{ }^{5}$ we obtain

$$
K=\left[L G D \mathcal{N}\left[\frac{\mathcal{G}(P D)}{\sqrt{1-R}}+\sqrt{\frac{R}{1-R}} \mathcal{G}(0.999)\right]-P D L G D\right] \frac{1}{1-1.5 b}
$$

The $R W A$ of the exposure is then calculated as the product of factor $K$, the exposure and a number limiting the RWA to 12.5 times the equity requirement,

$$
\begin{aligned}
& \mathrm{RW}=12.5 \times K \\
& \text { Equity }=0.08 \times \mathrm{RW} \times \text { Exposure. }
\end{aligned}
$$

\footnotetext{
${ }^{3}$ For Repos BCBS (2017a) introduced a fix $\mathrm{M}=0.5$.

${ }^{4}$ The risk of a credit exposure is assumed to be increasing with its maturity date.

${ }^{5}$ Within the IRB approach banks use either standard values provided by the BCBS (2017) or they estimate the $L G D$ with own historical data (BCBS 2017). $L G D=45 \%$ is the BCBS value for senior debt.
} 
The BCBS (2017a) differentiates between Common Equity Tier 1 capital (CET1), consisting mostly out of the banks' common shares, additional Tier 1 (AT1) capital including e.g. preferred shares, and Tier 2 capital including supplementary capital e.g. revaluation reserves. The sum of CET1 and AT1 is called Tier 1 capital. Total capital is Tier 1 plus Tier 2 capital. Consequently, the minimum capital requirements consist of different components. On average, the bank has to buffer its risk-weighted investments on the asset side by at least $4.5 \%$ CET1, $1.5 \%$ AT1 and $2 \%$ Tier 2 capital on its liability side. Those components sum up to the basic $8 \%$ of bank capital (equity) requirement. ${ }^{6}$

The regulatory treatment of EU sovereign bonds is different. Currently, the regulation allows banks to assign a risk-weighing factor of zero to sovereign bonds (BCBS, 2017a). Banks can buy EU sovereign bonds without holding any equity buffers to insure this exposure. This exemption is based on the assumption that sovereign exposures are risk-free assets. However, the EU sovereign debt crisis challenged this assumption and triggered an intense debate about the inclusion of the banks' sovereign exposure in the capital requirement regulation. Provided that the sovereign bonds' $P D$ is known, the framework described in Equation (2)-(6) allows for calculating the amount of the banks' saved equity capital or, in other words, their lack of equity capital for sovereign exposure.

\subsection{Calibration of the Sovereign Exposure Prospective Default Risk}

Equation (4) requires the exposures' probability of default $P D$. The stress tests provide this information indirectly. The $P D$ can be calibrated from the prospective yields of sovereign bonds, which are available for each stress test scenario. The yield to maturity is the internal rate of return an investor would earn if the bond were bought at the market price and held until expiration, given that the coupons and the principal payments are made on schedule. The market price $B$ of a multiple year risk-free bond with an annual coupon of $C$ and the principle payment of $\hat{B}$ is the investment at the market price $B$ and the risk-free interest rate in this economy. This concept can be expanded for more periods, e.g., for $n$ years.

$$
B=\frac{C}{1+i}+\frac{C}{(1+i)^{2}}+\frac{C+\hat{B}}{(1+i)^{3}}+\ldots=\sum_{t=1}^{n} \frac{C}{(1+i)^{t}}+\frac{\hat{B}}{(1+i)^{n}} .
$$

The rate of return between two bonds, one of them risky and one risk-free, differ from each other by a risk premia or, in other words, a risk differential. Yawitz (1977) builds a

\footnotetext{
${ }^{6}$ We use the term equity requirement and capital requirement synonymously.
} 
model to calculate this so-called risk differential. The price of a risky bond with rate $r$ is

$$
B=\frac{C+\hat{B}}{1+r}
$$

The risky bond has a probability of default of $1-p$ implying a survival rate of $p$. This means that the expected "safe" cash flow of the bond in this one period case is $p(C+\hat{B})$, such that

$$
B=\frac{p(C+\hat{B})}{1+i} \Rightarrow \frac{p(C+\hat{B})}{1+i}=\frac{C+\hat{B}}{1+r} .
$$

Yawitz (1977) expands this expression to $n$ periods and introduces the possibility that, in case of default, the recovery rate for the default period's coupon and par value is $\gamma$. Thus, the price of the risky bond can be expressed by

$$
B=\sum_{t=1}^{n-1} \frac{p^{t-1}[p C+(1-p) \gamma(C+\hat{B})]}{(1+i)^{t}}+\frac{p^{n-1}[p(C+\hat{B})+(1-p) \gamma(C+\hat{B})]}{(1+i)^{n}}
$$

The first term is the sum of all expected coupon payments plus the recovery from liquidation if the bond issuer goes bankrupt before the last period of maturity. The second term describes the expected cash flow in the case of surviving until the last period. The probabilities resulting from a simple binominal tree such that e.g. the probability of no default until maturity is $p^{n}$ and the probability of a default in the last period is $p^{n-1}(1-p)$. A risky bond with infinite maturity has the par value of ${ }^{7}$

$$
\hat{B}=\frac{C}{r} \text {. }
$$

By inserting $\hat{B}$ into Equation (8), we obtain

$$
B=\sum_{t=1}^{n-1} \frac{p^{t-1}\left[p C+(1-p) \gamma\left(C+\frac{C}{r}\right)\right]}{(1+i)^{t}}+\frac{p^{n-1}\left[p\left(C+\frac{C}{r}\right)+(1-p) \gamma\left(C+\frac{C}{r}\right)\right]}{(1+i)^{n}}
$$

Given that the bond $B$ quotes at its par value, Yawitz (1977) achieves the following relationship between the risk-free rate, the risky rate, the probability of survival, and the recovery rate,

$$
r=\frac{1+i}{p+\gamma-p \gamma}-1
$$

\footnotetext{
${ }^{7}$ This result is very often used in finance basing on a geometric series. A Proof for this relationship can be found in various textbooks.
} 
After rearranging Equation (10) we obtain the survival probability of the risky bond

$$
p=\frac{1+i-\gamma-\gamma r}{(1+r)(1-\gamma)}
$$

and thus

$$
P D=1-p
$$

The EBA provides the yields $r$ for all stress test scenarios and future dates that must be used by the participating banks. The yields at the reporting dates, $n=0$, are the real observations at these points in time. Prospective yields for $n=1,2,3$ are provided by EBA (see Tables 2-4 in the Appendix). Those yields are used to calibrate prospective $P D$, risk weights and equity requirements. For determining the recovery rate $\gamma$, we use the pre-determined loss given default $L G D=0.45^{8}$ and obtain $\gamma=0.55$ as $\gamma=1-L G D$. Another important aspect is the choice of the risk-free rate $i$. We consider German bonds as risk-free and the German rate as risk-free interest rate. Moreover, by construction the German probability of default is zero. ${ }^{9}$

\subsection{Calibration of the Banks' Default Risk}

The nexus theory suggests that the risk embedded in the sovereign home exposure is special because the likelihood of future losses from this sovereign exposure also depends on the domestic banks' default risk. Schnabel and Schüwer (2016) measure the banks' default risk with a CDS and regress it on the home bias and on balance sheet data. Figure 2 shows the endogeneity problem embedded in this approach. The market estimates the default risk of bank $i$ expressed in the CDS price at time $t=1$ from the bank characteristics of $t=1$. Arrow (i) indicates the direction of causality in the model. However, the opposite direction could also be true as banks may base their decision to invest in sovereign exposure on their own default risk (Arrow (ii)).

[Figure 2 here]

The key element of this causality problem is the simultaneous measurement of the CDS and banks' characteristics. A truly causal model would require measuring the home bias prior to its potential impact on the bank risk. Then, taking on additional risks, according to the risk shifting theory, after having observed the own default probability is impossible. It is obvious that real market data hardly provide such a setting. However, the bank stress

\footnotetext{
${ }^{8}$ The $L G D=0.45$ assumption follows, in this case, the IRB assumption for senior debt (see Section 3.2).

${ }^{9}$ In the data, sovereign bonds of Luxembourg sometimes have smaller rates and could be considered as the risk-free asset too. However, the market volume of these bonds is small and, therefore, not suitable to function as the risk-free asset, but their probability of default is set to zero in the related scenarios.
} 
tests conducted by the European Banking Authority (EBA) provide exactly this sequence. Since the global financial crisis, the EBA tests the European bank's stability at regular intervals. The starting point is the banks' balance sheets data collected at a reporting date, usually the last day of the year before the publication of the planned test. Under the assumption of a static business model, banks are required to apply a baseline scenario and an adverse scenario to their balance sheet positions. In other words, the stress test requires banks to apply a moderate (baseline) or extreme (adverse) shock occurring in time $t$ to their current balance sheet positions and calibrating how the positions' value would develop over time given that no adaption of the own strategy is possible. We use these calibrated simulation outcomes for the analysis of the impact of the home bias on banks' balance sheets. This design guarantees that endogeneity is not an issue. Figure 3 provides a graphical description of the approach.

\section{[Figure 3 here]}

The simulation results indicate whether the bank's equity buffer is large enough to absorb the impact of future negative shocks even if they are extreme (adverse). Absorption implies that the ratio of equity buffer to the risk-weighted assets stays above a predefined threshold. In this case, the bank stays solvent. Otherwise, the bank would have failed. Formally, with $T$ as the type of the stress scenario and $t$ as the date of the stress test, the bank $i$ 's status variable Failed is defined as follows:

$$
\text { Failed }_{i, t}^{j}=\left\{\begin{array}{rr}
1, & \text { if } \exists\left(\frac{C E T 1_{i, T}}{R W A_{i, T}}\right)^{j}<\text { Threshold in a scenario } \mathrm{T} \in[\text { baseline, adverse }] \\
& \text { of a stress test at time } t=\{2011,2014,2016\} \\
0, & \text { else. }
\end{array}\right.
$$

Common Equity Tier1 capital (CET1) indicates bank capital and $R W A$ the risk weighted assets. ${ }^{10}$ Table 1 illustrates what stress tests are included in the sample, the future dates $n$ that each stress test applies to, and the two possible scenarios $T$ for each future date. Note that the equity ratios that banks achieve in the two scenarios for each future date $n=1,2$ (stress test $t=2011$ ) and $n=1,2,3$ (stress tests $t=2014$ and $t=2016$ ) are pooled. If the bank achieves an equity ratio in stress test $t$ that is below the thresholds at least one time then the indicator Failed is set to $1 .{ }^{11}$ We distinguish between three different

\footnotetext{
${ }^{10}$ In principle, one could also consider different equity ratios, such the Tier 1 capital ratio. However, EBA only published for the 2011 stress test the results of the CET1 capital ratio. Thus, we constrain ourselves to this ratio.

${ }^{11}$ Consider the following example for stress test $t=2011$. Each bank provides ongoing characteristics, that is balance sheet items, observed by the end of $2010(n=0)$. Then, for each bank, the prospective equity ratio in date $2011(n=1)$ for the baseline scenario and the adverse scenario is calibrated. The same is done in date $2012(n=2)$. Given the two scenarios and the two prospective dates each bank faces 4
} 
Table 1: Simulated Years in the Stress Test Scenarios

\begin{tabular}{c||c|c|c}
\hline $\begin{array}{c}\text { Scenario } \\
\mathrm{T}\end{array}$ & $\begin{array}{c}\text { Stress Test } t=2011 \\
\text { Simulated Years } \\
(\mathrm{n} \in[1,2])\end{array}$ & $\begin{array}{c}\text { Stress Test } t=2014 \\
\text { Simulated Years } \\
(\mathrm{n} \in[1,2,3])\end{array}$ & $\begin{array}{c}\text { Stress Test } t=2016 \\
\text { Simulated Years } \\
(\mathrm{n} \in[1,2,3])\end{array}$ \\
\hline Baseline & 2011,2012 & $2014,2015,2016$ & $2016,2017,2018$ \\
Adverse & 2011,2012 & $2014,2015,2016$ & $2016,2017,2018$ \\
\hline
\end{tabular}

specifications of the equity ratios. The basic specification, $j=1$, mirrors the current regulation and completely neglects the bank's potential capital requirement for sovereign exposure. The second specification, $j=2$, partly accounts for the sovereign exposure risk by adding its risk weights to the $R W A$ s. Finally, the third specification, $j=3$, fully recognizes capital requirements for the sovereign exposure when calibrating the equity ratios.

$$
\left(\frac{C E T 1_{i, t}}{R W A_{i, t}}\right)^{j}= \begin{cases}\frac{C E T 1_{i, t}}{R W A_{i, t}} & \text { if } j=1 \\ \frac{C E T 1_{i, t}}{R W A_{i, t}+R W E U \text { Sovereigns }_{i, t}} & \text { if } j=2 \\ \frac{C E T 1_{i, t}+\text { Additional Equity }}{R W, t} & \text { if } j=3 .\end{cases}
$$

To obtain $R W E U$ Sovereigns of bank $i$ for every scenario and future data of the stress test, we calculate for a bond issued by country $c$ the risk weight $R W_{c, t}$ in the prospective dates $n \in[1,2,3]$. Application of Equation (11) yields the required $P D$ for each scenario and date. Inserting it into Equation (4) and rearranging delivers $K$. The risk-weight per country $c, R W_{c, t}$ is obtained from Equation (5). After multiplication with the sovereign exposure to country $c$ in the bank's books and aggregating the result over all EU countries, we obtain the bank's total risk-weighted sovereign debt exposure. ${ }^{12}$

$$
\text { RW EU Sovereigns }_{i, t}=\sum_{c=1}^{28} R W_{c, t} \times \text { Sovereign Exposure }_{c, t} .
$$

All variables are based on $C E T 1$, therefore Equation (6) is applied with a $4.5 \%$ minimal CET1 requirement to obtain the required Additional Equity. In $t=0$, bank management cannot observe the future equity ratios that they would achieve in the different scenarios and post stress test years. Therefore, in our framework, the possibility of risk shifting after observing the probability of default can be excluded. The reverse causality issue disappears.

prospective equity ratios. If at least one of those prospective equity ratios is below the threshold, we label the bank as Failed. We proceed in the same way for the stress test in $t=2014$ and $t=2016$. In these latter stress test banks face 6 different equity ratios as the number of prospective dates was increased to $n=3$.

${ }^{12}$ The same methodology is applied for calculating the risk-weighted sovereign debt exposure used in the failed variable in $j=2$ and $j=3$ (see Table 5). 


\section{Empirical Analysis}

\subsection{Estimation Models}

Our main hypothesis is that the home bias affects the bank's probability of default. To test the hypothesis, we model the probability of default as a function of the home bias,

$$
\operatorname{Pr}\left[y_{i, t} \mid x_{i, t}, \beta, \alpha_{i}\right]=\Lambda\left(\alpha_{i}+x_{i, t}^{\top} \beta\right) \quad, \text { with: } \Lambda(z)=\frac{e^{z}}{1+e^{z}} .
$$

$\Lambda(\cdot)$ denotes the logistic cumulative distribution function. The $\alpha_{i}$ is the individual bank effect. $x_{i, t}^{\top}$ reflects the transposed observations of the explanatory variables and $\beta$ is the vector of coefficients.

In principle, the data is structure as a panel, because banks are observed in three different stress tests. However, the panel is strongly unbalanced. Some banks are observed in only one stress test. With only three waves, the number of observation dates is also rather small. ${ }^{13}$ Therefore, we pool the data for all three stress tests. ${ }^{14}$ We apply clusterrobust standard errors and group the observations at the bank level. ${ }^{15}$ To obtain unbiased estimates we need to assume that the error term is uncorrelated with the explanatory

\footnotetext{
${ }^{13}$ There are several reasons for the unbalanced dataset: The criteria for the minimum size of a bank that would require it to participate in a stress test changed between 2011 and 2016. Moreover, mergers within the European banking market affected the sample. However, one cannot simply drop all banks not tested in all the stress tests because, in this case, there would be the probability that only large banks with good balance sheets would remain in the sample. In this case, the sample would not be representative of the European banking sector. Therefore, all observed banks are included in the analysis. Moreover, this would strongly reduce the number of available observations, which, in turn, would negatively affect the standard errors of the estimations. Based on the binary outcome data of the dependent variable, one must fit a nonlinear model using the panel data.

${ }^{14}$ The notation follows Cameron and Trivedi (2005). In principle, a fixed effects, a random effects, or a pooled model could be used. These models differ from each other in the assumptions behind the individual effects $\alpha_{i}$ and the applied estimation methods. Given the low number of observations and the relatively small variation in the equity ratio, using a fixed effects model is not appropriate. Alternatively, one could use a random effects model or a pooled model. The pooled model is based on the assumption that the bank individual specific effects are equal for each bank. Thus, it follows directly $\alpha_{i}=\alpha$. The pooled model estimates an averaged model using the same methods as the basic cross-sectional model. The estimators of the random and the pooled models are asymptotically equivalent in linear models. However, in the nonlinear case, the estimates may differ. Szmaragd, Clarke, and Steele (2013) provide a illustrative graphic for this difference between the random and pooled models in the nonlinear model world.

${ }^{15}$ One should note that the estimation of the coefficients is based on the cross-sectional data and not on the panel data. However, to be consistent with the notation introduced by Cameron and Trivedi (2005), the model includes time subscripts.
} 
variables. The basic regression equation is

$$
\begin{array}{r}
\operatorname{Pr}\left[\text { Failed }_{i, t}^{j} \mid x_{i, t}\right]=\Lambda\left(\beta_{0}+\beta_{1} \text { Home Bias }_{i, t}+\beta_{2}\right. \text { PD Home Country } \\
i, t
\end{array}
$$

The dependent variable is the Failed-indicator as defined in Equation (13). The key variables of interest are the Home Bias, as calculated in Equation (1), and its interaction effect with the country's probability of default at time $t$ as obtained from Equation (11), PD Home Country $\times$ Home Bias. ${ }^{16}$

The design of the stress tests is such that the calibrated equity ratios in the different stress test scenarios are independent of the banks' sovereign exposure. Thus, no direct channel between a bank's investments in EU sovereign bonds and the dependent variable, the calibrated future equity ratio, exists. Therefore, we expect that the home bias in Regression (15) has no impact on the bank's prospective probability of default. Following Beck, Jakubik, and Piloiu (2013), we include GDP growth as a macroeconomic driver of non-performing loan ratios that can threaten the banks' solvency.

The stress tests changed over the years. To account for these differences, stress test dummy variables are included with the stress test 2016 as the base category. The control variable Equity ${ }^{j}$ is the CETI capital ratio with which the bank enters the stress test. In other words, Equity ${ }^{j}$ is defined as the bank's common equity Tier 1 capital to riskweighted assets in time $t=0$. This variable is important because the equity measured at the reporting date possibly makes up a large amount of the future equity ratio calibrated in the stress test scenarios. Based on theory, e.g. Koehn and Santomero (1980), we expect a negative sign of the coefficient. Finally, the size of the bank is included to capture potential differences between small and big banks. The Size is measured as the ratio of banks' total assets and the average total assets of all banks in the sample, which is $318455.2 \mathrm{~m}$ Euro. A Size variable for a bank with an average amount of total assets has the value of 1 . Banks with larger values have more business activities than average banks, whereas a smaller value indicates that the bank is smaller than average. Larger banks benefit from the economies of scale, e.g., through better utilization of their information technology systems. Therefore, a negative sign is expected for the estimated coefficients

\footnotetext{
${ }^{16}$ For the calculation of the probability of default, see Subsection 3.3. In principle, other country characteristic could be used for indicating this solvency risk; for example, the debt to GDP as used in Schnabel and Schüwer (2016) or the credit rating of the government. However, as the yields of the bonds are available in the EBA database and allow for directly calibrating the countries' PDs, we prefer this indicator over the other options. The yields of the sovereign bonds reflect the economic conditions in the countries (Baldacci \& Kumar, 2010; Reinhart, Reinhart, \& Rogoff, 2012).
} 
of this parameter. The description of the variables is provided in Table 5 .

[Table 5 here]

\subsection{Data}

The overall sample includes all EU banks that participated in the stress tests EBA (2011), EBA (2014), and EBA (2016); though not every bank was examined in every test. ${ }^{17}$ The focus of the EBA changes over the years such that the test from 2014 contains more banks than in 2011 and 2016. Table 6 presents the data sources.

\section{[Table 6 here]}

The EBA collected bank data at the reporting date of the stress test $(t=0)$. In addition, the banks deliver the results of simulating the outcomes of distinct hypothetical scenarios. Each stress test includes a baseline scenario and an adverse scenario (Table 1). The independent variables in Regression (15) are based on data observed at $t=0$, which is the last day of the previous year prior to the stress test year. The binary dependent variable Failed is calibrated from Equation (12) and (13). It is one, if the simulated equity ratio is lower than the threshold in at least one of the $n$ future years of the two scenarios. Table 7 shows the default probability calibrated for distinct CET1-thresholds and for separate stress tests.

\section{[Table 7 here]}

Table 8 reports summary statistics. The minimum of the PD Home Country is zero in all samples because, at least, German bonds are assumed to be risk-free. Furthermore, the Home Bias differs widely across banks, even zero investments in home sovereign exposure occurs. However, most banks overweigh home sovereign exposure. On average, the banks invest 41.57 times as much in home sovereign bonds as a sovereign portfolio exactly mirroring the portions of the reference portfolio would allow. The average riskweighted home bias indicator is naturally smaller since, in some cases, the Home Bias is multiplied by a zero PD Home Country. The observed Equity variable in the base specification $(j=1)$ varies between $-4 \%$ and $73 \%$. Some banks entered the stress test with negative CET1 capital ratios. However, on average one observes an improvement of the equity ratio over the observation period. Due to stricter regulation, European banks built up CET1 capital between the end of 2010 and the end of 2015.

\footnotetext{
${ }^{17}$ The raw data of the stress tests is online: https://eba.europa.eu/risk-analysis-and-data/eu-wide-stresstesting (last accessed 18.02.2019). The 2011 raw data are difficult to handle because of a complex data structure.
} 
[Table 8 here]

The size variable measures the size of the banks relative to the average size of all banks in the sample and, thus, averages 1 . Some differences are observable across stress tests. The same applies for the ROA. The minimum ROA is negative for the 2011 and 2014 stress tests. However, the European banking sector improved its profitability over the years. The average ROA of banks stress tested in the 2016-exercise is higher than in the previous stress tests.

\section{Results}

We fit a Logit model to study how the propensity to default depends on the home bias and the other explanatory variables. ${ }^{18}$ Generally, fixing the minimum capital ratio threshold is a normative decision taken by regulators. We test three different thresholds of the CET1 capital ratio starting from the 5.5\% level, which was the hurdle rate in the 2014 stress test. ${ }^{19}$ Table 9 presents the findings for the basic model. A coefficient with a negative sign reduces banks' probability of a fall below the threshold, while a coefficient with a positive sign increases this probability.

[Table 9 here]

The coefficients in Table 9 of both the variable PD Home Country and the interaction effect $P D$ Home Country $\times$ Home Bias are highly significant and positive. This indicates a significantly lower propensity to default for banks located in a highly solvent country, no matter how large the home bias is. Interestingly, the Home Bias as such displays a significantly negative sign.

The Equity variable shows the expected negative sign and is highly significant for all thresholds. This result confirms the stabilizing effects of the bank capital. Size uniquely and significantly decreases the propensity to default no matter how high the hurdle for staying solvent is defined. The same applies for $R O A$. The finding supports the notion that the current $R O A$ is the equity buffer of the future. The time dummies are highly significant for all thresholds. This observation suggests that the propensity to achieve a large CET1 capital ratio was higher in the 2016 stress test than in previous ones. The statistics of the McFadden pseudo $R^{2}$ provides clear evidence that the model fits the data better than the null model.

\footnotetext{
${ }^{18}$ To put the different variables on the same scale we subtract the mean and divide by the standard deviation.

${ }^{19}$ In the other stress tests, no strict hurdle rates were implemented.
} 
Table 10 presents the estimation of the average marginal effects (AME). The AME allow to assess the magnitude of the impact of a small change in the variable of interest on the probability of default.

[Table 10 here]

For all three thresholds the AME of the home bias are insignificant. In contrast a small increase of the PD Home Country significantly increases a bank's probability of default. In the next step, we illustrate the dependence of the marginal effect on the home sovereign' solvency. For this purpose, we fix all other variables in the basic model at their mean and estimate the conditional marginal effects for different quantiles of PD Home Country. The blue solid line in the first graph of Figure 4 illustrates the progress of the marginal effect of the home bias for a CETI capital threshold of $5.5 \% .^{20}$

[Figure 4 here]

The dashed lines indicate the confidence intervals. It is obvious that the significance of the marginal effect depends on the PD Home Country. As long as the home country's default probability is low, the home bias significantly decreases the bank's default probability. In contrast, if the PD Home Country is large, the marginal effect is significantly positive. A small PD Home Country range in between those two ranges yields non-significant results implying that the PD Home Country has no impact on bank stability.

[Table 11 here]

In Table 11, we account for the risk of EU Sovereign bonds in the binary dependent variable. Adding the sovereign exposure risk lowers the equity capital ratios achieved per stress test in the future years of the two scenarios. The estimation again yields a positive and significant coefficient for the interaction effect PD Home Country $\times$ Home Bias. The stand-alone effect of home bias is significantly negative throughout all thresholds. This difference between the two home bias variables indicates that the riskiness of the home sovereign bond is an important factor within the nexus. The PD Home Country loses its strong significance.

The equity variable remains highly significant with a negative sign. This result emphasizes again that a higher CET1 capital ratio in $t=0$ lowers the propensity to default on a predefined threshold of the minimum capital ratio in one of stress test scenarios in future years. The results for the Size variable are also stable. The effect of the ROA mirrors the home bias result and becomes significant even for lower thresholds. Only the stress test dummy results differ from the basic model. The dates are largely insignificant for all thresholds.

\footnotetext{
${ }^{20}$ The results for the other thresholds are comparable to the $5.5 \%$ threshold.
} 
[Table 12 here]

Table 12 reports the AME of model $j=2$. In this specification, a small increase in the home bias significantly reduces the banks' probability of default. However, the corresponding graph in Figure 4 again shows that direction and significance of the marginal impact of the home bias depends on the home country's position in the distribution of the default probabilities.

Finally, we study the impact of the home bias on banks' likelihood to overcome the capital threshold, assuming the bank has already applied the IRB basic approach to their EU sovereign exposure (Model $j=3$ ). To transform the banks in our sample into fully complying banks, we apply Equation (12). Table 13 presents the estimations for hypothetically fully complying banks.

\section{[Table 13 here]}

The obtained coefficients confirm the previous results. The findings for the Home Bias and the interaction effect show the same signs as in the other specifications except that the imputed additional equity makes it easier to overcoming the threshold. ${ }^{21}$

\section{[Table 14 here]}

Tables 14 present the respective AME estimates. The insignificance of the home bias variable for lower thresholds clearly indicates that, in this range, the imputed additional CET1 capital renders the home bias less significant for bank's default probability. However, in case of the largest threshold, the AME is negative and significant. Those estimation results suggest that imposing CETl capital requirements for sovereign exposure and combining it with a high capital threshold would tend to stabilize banks rather than destabilize them.

Interestingly, for larger thresholds, which imply a larger default probability (see Table 7), the starting CET1 capital ratio becomes more important. The lower graph in Figure 4 illustrates the conditional marginal effects of the home bias for different quantiles of the variable PD Home Country for the (hypothetically) complying banks. Again, we observe a switching of the sign for larger values of the PD Home Country, thus indicating that there is no general effect of the home bias. In fact, the impact of the home bias on bank stability depends on the risk of the home sovereign exposure; thus, in other words, the home country's risk matters. To study the impact of a larger additional CET1 capital requirement than the current regulation would imply, we assume in Figure 5 a fictive $25 \%$ CET1 capital requirement of risk weighted EU sovereign bonds on banks' balance sheets. The threshold is set to $5.5 \% .^{22}$ One observes a strong impact of this larger capital

\footnotetext{
${ }^{21}$ The pseudo $R^{2}$ provides evidence that the model fits the data better than the null model in all three specifications. The calculated pseudo $R^{2}$ are relatively close to each other across the three models.

${ }^{22}$ The results for the other thresholds are comparable to the $5.5 \%$ threshold.
} 
requirement. The sign of the marginal effect of the home bias indicates a stabilizing effect even for banks located in countries with high default probabilities. This result provides support for the hypothesis that additional CETI capital is a way to reduce the nexus. However, the requirement must be larger than it is in the currently actual applied framework.

[Figure 5 here]

Our findings on the stabilizing effect of an independent equity ratio supports Schnabel and Schüwer (2016). The same applies for the positive impact of the interaction effect in the pure logit model. However, they find a significant destabilizing effect for stand-alone home bias, which contrasts starkly with our findings. There may be several underlying reasons ranging from using a distinct sample - their sample includes only banks that were tested in all stress tests - over the fact that they use daily CDS data and interpolate banks' characteristics between the reporting dates of the stress tests to generate more observations. Moreover, they exclude some European banks, excluding, among others, Greek banks.

\section{Summary and Conclusion}

This paper studies the impact of banks' home bias in sovereign bonds on banks' stability on the basis of the nexus theory. Banks investing strongly in sovereign bonds of their home country are exposed to a deterioration of their sovereign's solvency risk. The market value of the home bonds among bank assets suffers, ultimately threatening a bank's solvency. The so-called feedback loop is in action because of the increased risk of a bank bailout, reduced economic growth, and reduced tax revenues for the sovereign state.

The literature is increasingly exploring the linkages between banks and their home sovereigns. The studies often focus on banks' sovereign home bias as a crucial driver of an increased sovereign solvency risk. In contrast, research on the impact of the home bias on the stability of banks is rare. The presented methodological framework offers new insights into the home bias-bank stability relationship. To disentangle the different effects of the banks' home sovereign investment, we introduce a "risk-weighted home bias," interacting the home sovereign exposure with the home country's default probability. The comparison of the Logit models' odds ratios and the respective marginal effects clearly reveal that the "risk-weighted home bias" matters. By and large, we find that the home bias stabilizes banks. However, we also show that there is no such thing as a unique effect of the home bias on bank stability. The impact of the home bias depends on the home country's default risk and on changes from stability increasing in the lower $P D$ ranges to 
stability decreasing in higher ranges. These findings stand in stark contrast to the current assumption of risk-free EU sovereign bonds as applied in the financial regulatory framework. Other bank characteristics are also drivers of banks' stability. CETl bank capital stabilizes bank. Accordingly, abolishing the equity privilege can be expected to reduce the dependence of the bank's probability of default on the home sovereigns solvency.

Our results support the conceptual idea behind the nexus theory. Interestingly, the holding of sovereign bonds of the home country is not necessarily destabilizing for the bank. Investments in home sovereign bonds may improve banks' stability if the default probability of the sovereign is small. Regulation focusing on home bias should account for heterogeneous effects depending on the home country's solvency. The findings clearly support risk buffering through CETI bank capital. Additional bank capital requirements for EU sovereign bonds would reduce banks' probability of a fall below a certain minimum threshold in normal and adverse states of the economy.

Our research neglects the consequences of introducing additional equity buffering for sovereign funding as well as repercussions from possibly constrained funding for the stability of the Euro zone as a whole. As those effects can be severe, careful policy making, gradual implementation, and a long period of transition are advised. Studying the best regulation regime and transition path is left for future research. 


\section{Appendix}

\section{Figures and Tables}

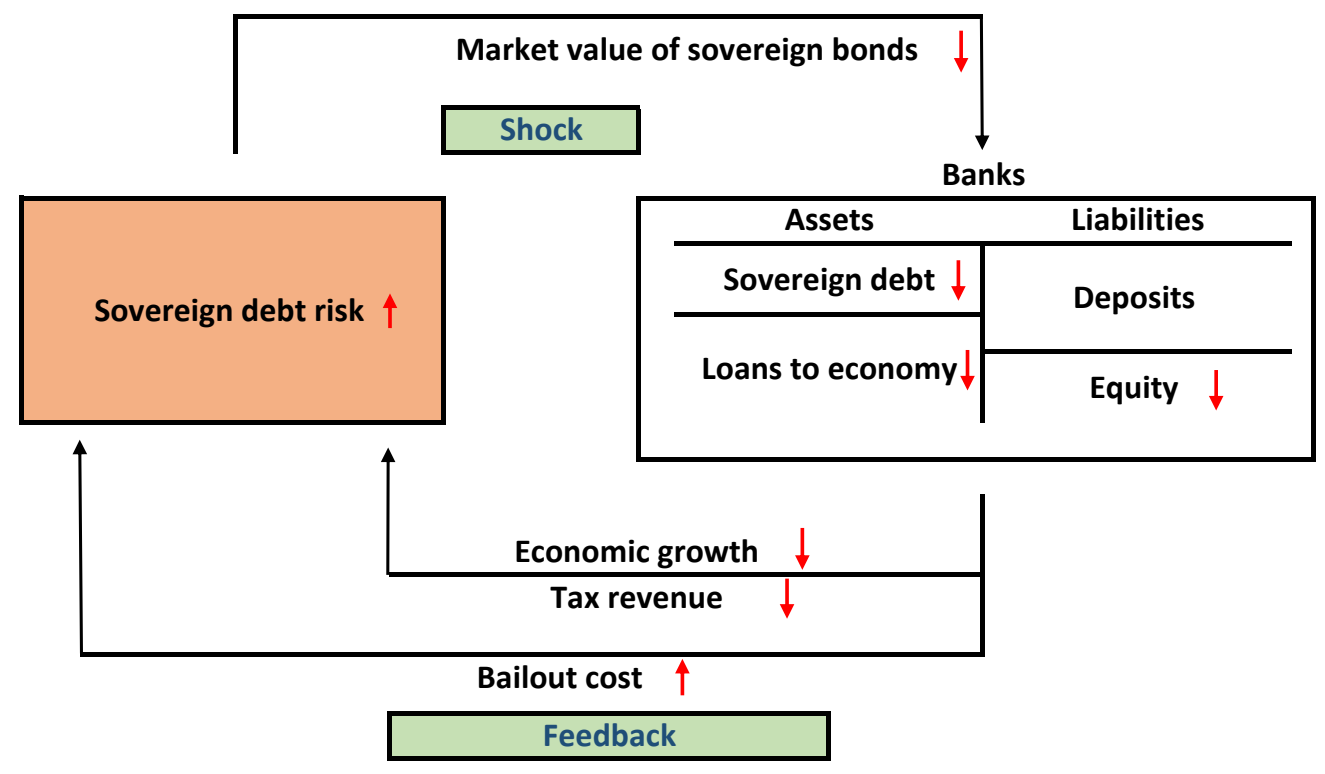

Figure 1: The Sovereign-Banking Nexus Own Illustration based on Brunnermeier et al. (2016) 


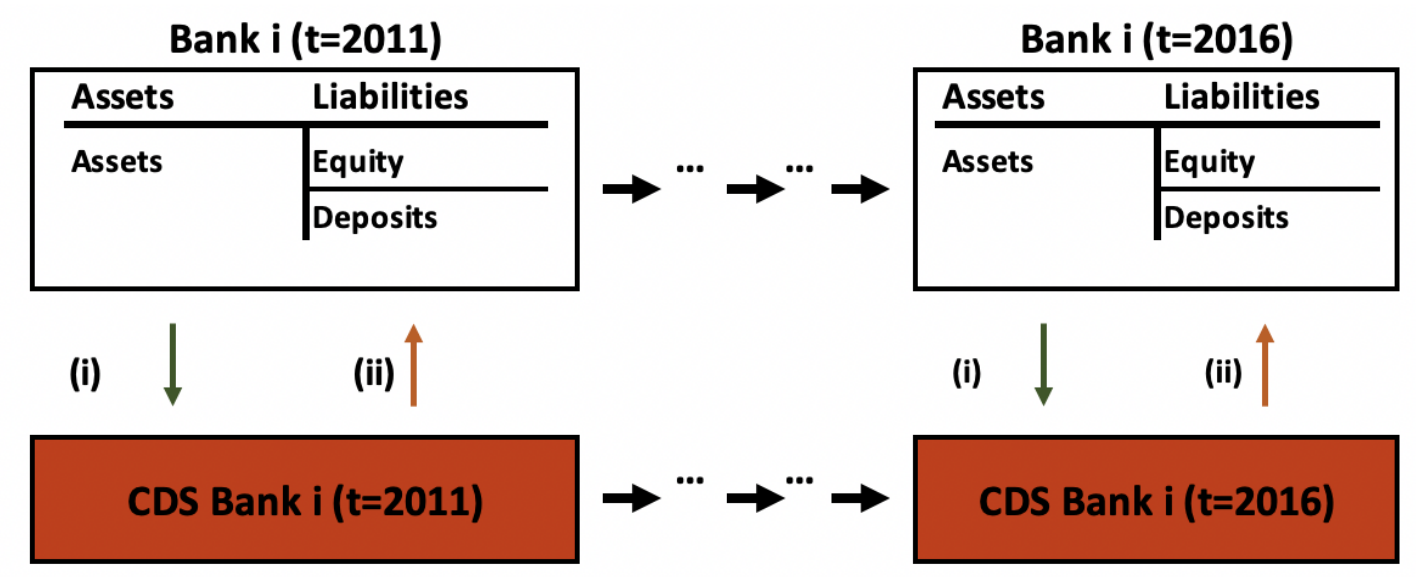

Figure 2: The Causality Problem in the Existing Approach (Own Illustration)

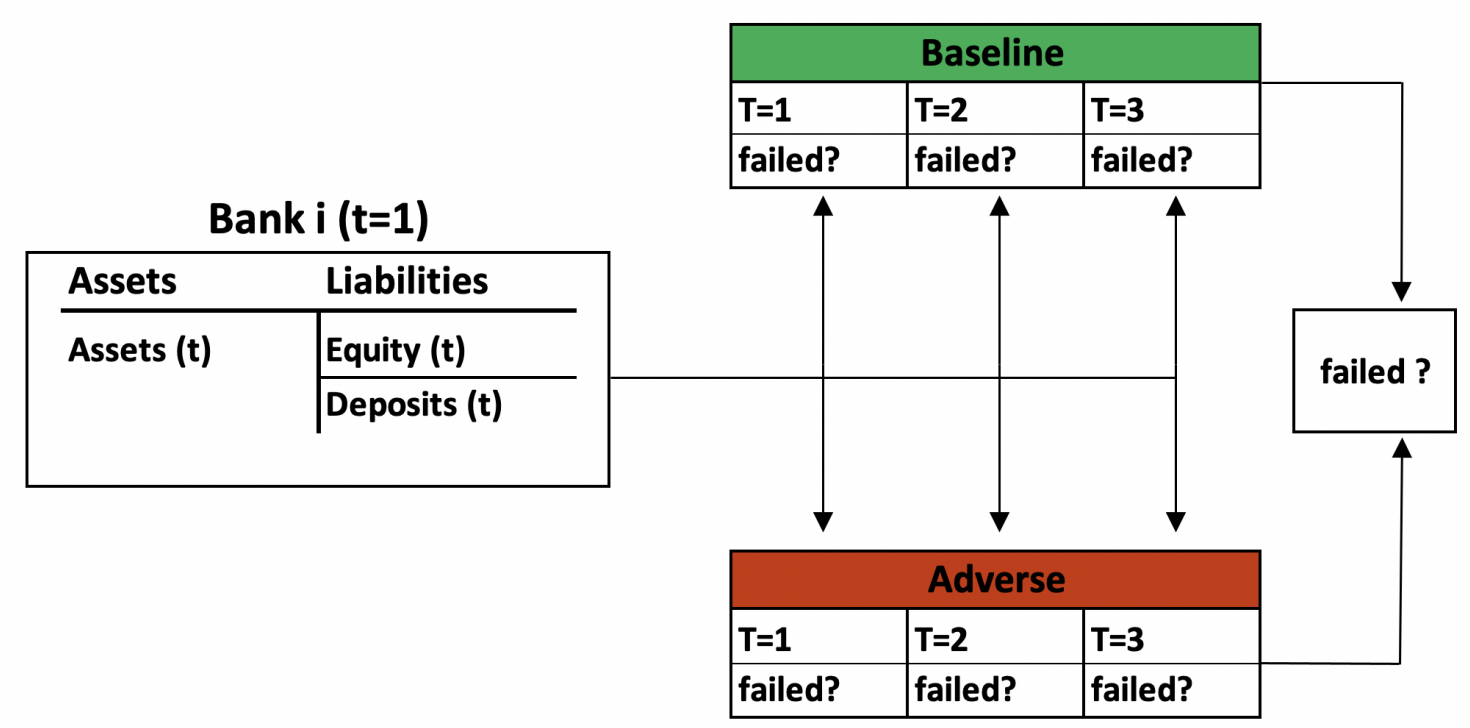

Figure 3: Illustration of the Failed Variable (Own Illustration) 
Table 2: Yields of 10 Years EU Sovereign Bonds in the Stress Test 2011 (in \%)

\begin{tabular}{l||c|c|c|c|c}
\hline \multicolumn{1}{l||}{} & \multicolumn{3}{|c}{ Scenarios } \\
Country & Base Year & \multicolumn{3}{|c}{$\mathrm{T}=$ baseline } & $\mathrm{T}=$ adverse \\
& 2010 & 2011 & 2012 & 2011 & 2012 \\
& & $n=1$ & $n=2$ & $n=1$ & $n=2$ \\
\hline Austria & 3.2 & 3.1 & 3.3 & 3.3 & 3.5 \\
Belgium & 3.4 & 3.6 & 3.8 & 4.4 & 4.6 \\
Bulgaria & 6.1 & 6.3 & 6.5 & 7.1 & 7.3 \\
Cyprus & 4.6 & 5 & 5.2 & 6.4 & 6.6 \\
Czech Republic & 3.9 & 3.8 & 4 & 4.1 & 4.3 \\
Denmark & 2.9 & 2.8 & 3 & 3 & 3.2 \\
Estonia & 5.9 & 5.5 & 5.7 & 5.9 & 6.1 \\
Finland & 3 & 2.9 & 3.1 & 3 & 3.2 \\
France & 3.1 & 3.1 & 3.3 & 3.6 & 3.8 \\
Germany & 2.7 & 2.7 & 2.9 & 2.7 & 2.9 \\
Greece & 9 & 11.5 & 11.7 & 14.1 & 14.3 \\
Hungary & 7.2 & 7.1 & 7.1 & 8.2 & 8.2 \\
Ireland & 5.7 & 8.6 & 8.8 & 11.2 & 11.4 \\
Italy & 4 & 4.3 & 4.5 & 5.7 & 5.9 \\
Latvia & 10.7 & 10.4 & 10.6 & 11 & 11.2 \\
Lithuania & 5.6 & 5.5 & 5.7 & 6.1 & 6.3 \\
Luxembourg & 3.1 & 3.1 & 3.3 & 3.9 & 4.1 \\
Malta & 4.2 & 4.3 & 4.5 & 5.7 & 5.9 \\
Netherlands & 2.9 & 2.9 & 3.1 & 3.1 & 3.3 \\
Poland & 5.8 & 5.8 & 5.7 & 6.5 & 6.4 \\
Portugal & 5.4 & 6.9 & 7.1 & 9.4 & 9.6 \\
Romania & 7.4 & 7.5 & 7.7 & 8.4 & 8.6 \\
Slovakia & 3.8 & 4 & 4.2 & 4.3 & 4.5 \\
Slovenia & 3.8 & 4 & 4.2 & 4.4 & 4.6 \\
Spain & 4.2 & 4.7 & 4.9 & 6.4 & 6.6 \\
Sweden & 2.8 & 3 & 3.1 & 3.1 & 3.2 \\
United Kingdom & 3.4 & 3.5 & 3.8 & 3.8 & 4.1 \\
\hline & & & & &
\end{tabular}

The raw data used for this table: https://www.eba.europa.eu/documents/10180/15932/EBAST-2011-004-Annex-3-Detailed-overall-scenario-table_-EEA_1.pdf (date of most recent download: 24.10.2018). 
Table 3: Yields of 10 Years EU Sovereign Bonds in the Stress Test 2014 (in \%)

\begin{tabular}{|c|c|c|c|c|c|c|c|}
\hline \multirow[b]{3}{*}{ Country } & \multirow{3}{*}{$\begin{array}{c}\text { Base Year } \\
2013\end{array}$} & \multicolumn{6}{|c|}{ Scenarios } \\
\hline & & \multicolumn{3}{|c|}{$\mathrm{T}=$ baseline } & \multicolumn{3}{|c|}{$\mathrm{T}=$ adverse } \\
\hline & & $\begin{array}{c}2014 \\
n=1\end{array}$ & $\begin{array}{c}2015 \\
n=2\end{array}$ & $\begin{array}{c}2016 \\
n=3\end{array}$ & $\begin{array}{c}2014 \\
n=1\end{array}$ & $\begin{array}{l}2015 \\
n=2\end{array}$ & $\begin{array}{c}2016 \\
n=3\end{array}$ \\
\hline Austria & 2 & 2.1 & 2.4 & 2.5 & 3.4 & 3.4 & 3.5 \\
\hline Belgium & 2.4 & 2.5 & 2.8 & 2.9 & 3.9 & 3.9 & 4 \\
\hline Bulgaria & 3.5 & 3.6 & 3.9 & 4 & 5.1 & 5 & 5.1 \\
\hline Croatia & 4.7 & 5.1 & 5.4 & 5.5 & 6.7 & 6.6 & 6.7 \\
\hline Cyprus & 11.1 & 8.3 & 8.6 & 8.7 & 9.7 & 9.6 & 9.7 \\
\hline Czech Republic & 2.1 & 2.4 & 2.7 & 2.8 & 3.9 & 3.8 & 3.9 \\
\hline Denmark & 1.7 & 1.8 & 2.1 & 2.3 & 3.1 & 3 & 3.2 \\
\hline Finland & 1.9 & 1.9 & 2.2 & 2.3 & 3.2 & 3.1 & 3.2 \\
\hline France & 2.2 & 2.4 & 2.7 & 2.8 & 3.8 & 3.7 & 3.8 \\
\hline Germany & 1.6 & 1.8 & 2.1 & 2.2 & 2.9 & 2.9 & 3 \\
\hline Greece & 10.1 & 8 & 8.3 & 8.4 & 11.2 & 10.6 & 10.7 \\
\hline Hungary & 5.9 & 6.1 & 6.5 & 6.6 & 7.9 & 7.8 & 7.9 \\
\hline Ireland & 3.8 & 3.4 & 3.7 & 3.8 & 4.9 & 4.8 & 4.9 \\
\hline Italy & 4.3 & 3.9 & 4.1 & 4.3 & 5.9 & 5.6 & 5.8 \\
\hline Latvia & 3.3 & 3.6 & 3.9 & 4 & 5.2 & 5 & 5.2 \\
\hline Lithuania & 3.8 & 3.4 & 3.7 & 3.9 & 4.6 & 4.6 & 4.7 \\
\hline Luxembourg & 1.7 & 1.9 & 2.1 & 2.3 & 3.4 & 3.3 & 3.4 \\
\hline Malta & 3.4 & 3.1 & 3.4 & 3.5 & 4.6 & 4.5 & 4.6 \\
\hline Netherlands & 2 & 2 & 2.3 & 2.4 & 3.3 & 3.3 & 3.4 \\
\hline Poland & 4 & 4.6 & 4.8 & 4.9 & 6.1 & 5.9 & 5.9 \\
\hline Portugal & 6.3 & 5.1 & 5.4 & 5.5 & 7.4 & 7.1 & 7.2 \\
\hline Romania & 5.4 & 5.2 & 5.5 & 5.7 & 6.9 & 6.7 & 6.8 \\
\hline Slovakia & 3.2 & 2.6 & 2.9 & 3 & 4.1 & 4 & 4.1 \\
\hline Slovenia & 5.8 & 4.8 & 5.1 & 5.2 & 6.5 & 6.4 & 6.5 \\
\hline Spain & 4.6 & 3.8 & 4.1 & 4.2 & 5.7 & 5.5 & 5.6 \\
\hline Sweden & 2.1 & 2.3 & 2.6 & 2.7 & 3.8 & 3.7 & 3.7 \\
\hline United Kingdom & 2 & 2.8 & 3.2 & 3.3 & 4.2 & 4.2 & 4.3 \\
\hline
\end{tabular}

The raw data used for this table: https://www.esrb.europa.eu/mppa/stress/shared/pdf/140430 Adverse-scenario_2014-EBA-stress-test.pdf?695421554f41f21fd7ea7e7216783622 (last downloaded 24.10.2018). 
Table 4: Yields of 10 Years EU Sovereign Bonds in the Stress Test 2016 (in \%)

\begin{tabular}{l||c|c|c|c|c|c|c}
\hline \multicolumn{1}{l|}{} & & \multicolumn{5}{|c}{ Scenarios } \\
Country & Base Year & \multicolumn{3}{|c}{$\mathrm{T}=$ baseline } & \multicolumn{3}{c}{$\mathrm{T}=$ adverse } \\
& 2015 & 2016 & 2017 & 2018 & 2016 & 2017 & 2018 \\
& & $n=1$ & $n=2$ & $n=3$ & $n=1$ & $n=2$ & $n=3$ \\
\hline Austria & 0.8 & 1 & 1.2 & 1.3 & 1.5 & 1.9 & 1.9 \\
Belgium & 0.9 & 1 & 1.2 & 1.3 & 1.7 & 2 & 1.9 \\
Bulgaria & 2.4 & 2.4 & 2.6 & 2.7 & 3.1 & 3.5 & 3.4 \\
Croatia & 3.5 & 4 & 4.2 & 4.2 & 4.6 & 5 & 4.9 \\
Cyprus & 4.6 & 4.1 & 4.3 & 4.4 & 4.8 & 5.1 & 5 \\
Czech Republic & 0.6 & 0.7 & 0.9 & 1 & 1.5 & 1.7 & 1.7 \\
Denmark & 0.7 & 1 & 1.3 & 1.3 & 1.6 & 1.9 & 1.9 \\
Finland & 0.7 & 1 & 1.2 & 1.2 & 1.5 & 1.9 & 1.8 \\
France & 0.9 & 1.1 & 1.3 & 1.4 & 1.6 & 2 & 2 \\
Germany & 0.5 & 0.7 & 0.9 & 1 & 1.2 & 1.6 & 1.5 \\
Greece & 10 & 8 & 8.2 & 8.3 & 10.4 & 9.9 & 9.8 \\
Hungary & 3.4 & 3.4 & 3.7 & 3.7 & 5.5 & 5.3 & 5.3 \\
Ireland & 1.2 & 1.3 & 1.5 & 1.6 & 2.1 & 2.4 & 2.3 \\
Italy & 1.7 & 1.8 & 2 & 2.1 & 2.9 & 3 & 3 \\
Latvia & 0.9 & 1.1 & 1.3 & 1.4 & 1.7 & 2.1 & 2 \\
Lithuania & 1.4 & 1.7 & 1.9 & 2 & 2.3 & 2.6 & 2.6 \\
Luxembourg & 0.4 & 0.5 & 0.7 & 0.8 & 1 & 1.4 & 1.4 \\
Malta & 1.5 & 1.7 & 1.9 & 1.9 & 2.3 & 2.6 & 2.6 \\
Netherlands & 0.7 & 0.9 & 1.1 & 1.2 & 1.4 & 1.8 & 1.7 \\
Poland & 2.7 & 2.7 & 2.9 & 2.9 & 4.4 & 4.4 & 4.4 \\
Portugal & 2.4 & 2.5 & 2.7 & 2.8 & 3.8 & 3.9 & 3.8 \\
Romania & 3.5 & 3.8 & 4 & 4.1 & 5 & 5.2 & 5.2 \\
Slovakia & 0.9 & 0.9 & 1.1 & 1.2 & 1.5 & 1.9 & 1.8 \\
Slovenia & 1.7 & 1.9 & 2.1 & 2.2 & 2.9 & 3.1 & 3 \\
Spain & 1.8 & 2 & 2.2 & 2.2 & 2.9 & 3.2 & 3.1 \\
Sweden & 0.7 & 0.9 & 1.2 & 1.2 & 1.5 & 2 & 1.9 \\
United Kingdom & 1.8 & 1.9 & 2.1 & 2.1 & 2.4 & 2.7 & 2.6 \\
\hline & & & & & &
\end{tabular}

The raw data used for this table: https://www.eba.europa.eu/documents/10180/1383302/2016 +EU-wide+stress+test-Adverse+macro-financial+scenario.pdf (last downloaded 24.10.2018). 
Table 5: Variables, Definitions and Expected Sign of Coefficient

\begin{tabular}{|c|c|c|}
\hline Variables & Definition & Expected Sign \\
\hline Failed $^{j}$ & $\begin{array}{l}\text { A dummy variable } \in[1,0] \text { indicating } \\
\text { an equity ratio lower than the threshold, } \\
\text { see Equation (12) }\end{array}$ & Dependent variable \\
\hline PD Home Country & Home country's default probability & + \\
\hline Home Bias & $\begin{array}{l}\text { Ratio of home sovereign exposure/EU sovereign exposure } \\
\text { and home GDP/EU GDP, see Equation (1) }\end{array}$ &,,$-+ ?$ \\
\hline RW & Risk weight for sovereign exposure, see Equation (4) & \\
\hline $\operatorname{RWA}(j=1)$ & Risk-weighted assets without sovereign exposure & \\
\hline $\operatorname{RWA}(j=2,3)$ & RWA $(j=1)$ plus RW EU Sovereigns & \\
\hline PD Home Country & & \\
\hline$\times$ Home Bias & Interaction effect of Home Bias and the home country's solvency &,,$-+ ?$ \\
\hline Equity $(j=1)$ & CET1 capital ratio without sovereign exposure, $\frac{C E T I}{R W A}$ & - \\
\hline Equity $(j=2)$ & $\begin{array}{l}\text { CET1 capital ratio plus risk-weighted sovereign exposure, } \\
\frac{C E T 1}{R W A+R W E U \text { Sovereigns }}\end{array}$ & - \\
\hline Equity $(j=3)$ & $\begin{array}{l}\text { CET1 capital ratio plus risk-weighted sovereign exposure } \\
\text { and additional CET1 capital, } \frac{C E T 1+\text { Additional Equity }}{R W A+R W E U \text { Sovereigns }}\end{array}$ & - \\
\hline Size & Total assets over average total assets, $\frac{\text { Total Assets }}{318459.3}$ & - \\
\hline Stress Test & A dummy variable $\in[1,0]$ for stress test $t$ & $?$ \\
\hline ROA & Bank profits before taxes over total assets, $\frac{\text { Return }}{\text { Total Assets }}$ & - \\
\hline Other Variables & Definition & \\
\hline CET1 & CET1 capital in bank's balance sheet & \\
\hline RW EU Sovereigns & $\sum_{c=1}^{28} R W_{c}$ Exposure $_{c, i}$ & \\
\hline Total Assets & Bank's total assets & \\
\hline Additional Equity & $0.045 * R W$ EU Sovereigns ${ }_{i}$ & \\
\hline Return & Bank's return before tax & \\
\hline Sov $_{\text {Home }}$ & Bank's home sovereigns & \\
\hline $\operatorname{Sov}_{E U}$ & Bank's total sovereigns & \\
\hline $\mathrm{GDP}_{\text {Home }}$ & GDP home country & \\
\hline $\mathrm{GDP}_{E U}$ & GDP EU & \\
\hline
\end{tabular}


Table 6: Data Sources

\begin{tabular}{ll||ll}
\hline Variabe & Source & Variable & Source \\
\hline Sov. Exposure & EBA & Sov. Yields & EC/ESRB \\
RWA & EBA & Additional Equity & Authors \\
CET1 & EBA & Return & EBA \\
Total Assets (2011) & EBA/Authors & Sov $_{E U}$ & EBA, Authors \\
Total Assets (2014) & Authors/ECB & $\operatorname{Sov}_{H o m e}$ & EBA \\
Total Assets (2016) & Authors collection & Equity $(j=1)_{\text {EBA }}$ & EBA \\
GDP $_{H o m e}$ & Worldbank & Equity $(j=2)$ & EBA, Authors \\
GDP $_{\text {EU }}$ & Worldbank & Equity $(j=3)$ & EBA, Authors \\
Home Bias & Authors & Size & Authors \\
RW Home Bias & Authors & PD Home Country & Authors \\
RW EU Sovereigns & Authors & ROA & Authors \\
\hline
\end{tabular}

Table 7: Bank's Probability of a Fall Below the Equity Ratio Threshold

\begin{tabular}{ccc||c|c|c}
\hline \multicolumn{1}{l|}{} & \multicolumn{1}{c||}{} & \multicolumn{3}{|c}{ Threshold } \\
& Year & $<\mathbf{5 . 5 \%}$ & $<\mathbf{6 . 0 \%}$ & $<\mathbf{6 . 5 \%}$ \\
& & Prob. & Prob. & Prob. \\
\hline & 2011 & $32.58 \%$ & $39.33 \%$ & $48.31 \%$ \\
& 2014 & $19.67 \%$ & $22.13 \%$ & $22.31 \%$ \\
1 & 2016 & $0.00 \%$ & $0.00 \%$ & $0.00 \%$ \\
& Total & $20.31 \%$ & $23.75 \%$ & $28.74 \%$ \\
\hline & 2011 & $50.56 \%$ & $61.80 \%$ & $68.54 \%$ \\
& 2014 & $34.43 \%$ & $45.08 \%$ & $51.64 \%$ \\
2 & 2016 & $10.00 \%$ & $18.00 \%$ & $28.00 \%$ \\
& Total & $35.25 \%$ & $45.59 \%$ & $52.87 \%$ \\
\hline & 2011 & $33.71 \%$ & $42.70 \%$ & $56.18 \%$ \\
& 2014 & $20.49 \%$ & $27.05 \%$ & $33.61 \%$ \\
3 & 2016 & $2.00 \%$ & $4.00 \%$ & $8.00 \%$ \\
& Total & $21.46 \%$ & $27.97 \%$ & $36.40 \%$ \\
\hline
\end{tabular}


Table 8: Summarizing Statistics for the Stress Tests 2011-2016 and the Total Sample

\begin{tabular}{|c|c|c|c|c|}
\hline & mean & sd & $\min$ & $\max$ \\
\hline & \multicolumn{4}{|c|}{ Total Sample (261 Observations) } \\
\hline PD Home Country & 0.03 & 0.04 & 0.00 & 0.19 \\
\hline Home Bias & 41.57 & 162.63 & 0.00 & 1715.47 \\
\hline PD Home Country $\times$ Home Bias & 2.64 & 12.38 & 0.00 & 135.12 \\
\hline Stresstest 2011 & 0.34 & 0.47 & 0.00 & 1.00 \\
\hline Stresstest 2014 & 0.47 & 0.50 & 0.00 & 1.00 \\
\hline Equity $(j=1)$ & 0.12 & 0.06 & -0.04 & 0.73 \\
\hline Equity $(j=2)$ & 0.09 & 0.04 & -0.02 & 0.32 \\
\hline Equity $(j=3)$ & 0.10 & 0.04 & -0.01 & 0.33 \\
\hline Size & 1.00 & 1.50 & 0.00 & 10.08 \\
\hline \multirow[t]{2}{*}{ ROA } & 0.01 & 0.01 & -0.09 & 0.06 \\
\hline & \multicolumn{4}{|c|}{ Stress Test 2011 as of 31.12 .2010 (89 Observations) } \\
\hline PD Home Country & 0.03 & 0.03 & 0.00 & 0.13 \\
\hline Home Bias & 46.67 & 185.06 & 0.96 & 1715.47 \\
\hline PD Home Country $\times$ Home Bias & 1.86 & 6.15 & 0.00 & 54.88 \\
\hline Equity $(j=1)$ & 0.09 & 0.04 & 0.04 & 0.28 \\
\hline Equity $(j=2)$ & 0.08 & 0.03 & 0.03 & 0.22 \\
\hline Equity $(j=3)$ & 0.08 & 0.03 & 0.04 & 0.22 \\
\hline Size & 0.96 & 1.43 & 0.00 & 6.27 \\
\hline \multirow[t]{2}{*}{ ROA } & 0.00 & 0.01 & -0.09 & 0.03 \\
\hline & \multicolumn{4}{|c|}{ Stress Test 2014 as of 31.12 .2013 (122 Observations) } \\
\hline PD Home Country & 0.04 & 0.05 & 0.00 & 0.19 \\
\hline Home Bias & 49.52 & 177.12 & 0.00 & 1679.99 \\
\hline PD Home Country $\times$ Home Bias & 4.18 & 17.21 & 0.00 & 135.12 \\
\hline Equity $(j=1)$ & 0.13 & 0.07 & -0.04 & 0.73 \\
\hline Equity $(j=2)$ & 0.09 & 0.04 & -0.02 & 0.27 \\
\hline Equity $(j=3)$ & 0.10 & 0.04 & -0.01 & 0.28 \\
\hline Size & 0.76 & 1.38 & 0.01 & 10.08 \\
\hline \multirow[t]{2}{*}{ ROA } & 0.01 & 0.01 & -0.02 & 0.05 \\
\hline & \multicolumn{4}{|c|}{ Stresstest 2016 as of 31.12 .2015 (50 Observations) } \\
\hline PD Home Country & 0.01 & 0.01 & 0.00 & 0.06 \\
\hline Home Bias & 13.08 & 18.27 & 0.00 & 113.86 \\
\hline PD Home Country $\times$ Home Bias & 0.29 & 1.01 & 0.00 & 7.10 \\
\hline Equity $(j=1)$ & 0.15 & 0.05 & 0.10 & 0.43 \\
\hline Equity $(j=2)$ & 0.12 & 0.05 & 0.05 & 0.32 \\
\hline Equity $(j=3)$ & 0.13 & 0.04 & 0.08 & 0.33 \\
\hline Size & 1.65 & 1.71 & 0.11 & 6.97 \\
\hline ROA & 0.02 & 0.01 & 0.00 & 0.06 \\
\hline
\end{tabular}


Table 9: Propensity to Default and Home Bias $(j=1)$

\begin{tabular}{|c|c|c|c|c|c|c|}
\hline & (1) & (2) & (3) & (4) & (5) & (6) \\
\hline & \multicolumn{2}{|c|}{ CET 1 ratio $<5.5 \%$} & \multicolumn{2}{|c|}{ CET1 ratio $<6.0 \%$} & \multicolumn{2}{|c|}{ CET1 ratio $<6.5 \%$} \\
\hline Home Bias & $\begin{array}{l}-0.0141 \\
(0.133)\end{array}$ & $\begin{array}{l}-2.079^{*} \\
(1.139)\end{array}$ & $\begin{array}{l}0.0633 \\
(0.145)\end{array}$ & $\begin{array}{l}-0.422 \\
(0.264)\end{array}$ & $\begin{array}{l}0.0681 \\
(0.149)\end{array}$ & $\begin{array}{c}-0.497^{* *} \\
(0.249)\end{array}$ \\
\hline PD Home Country & & $\begin{array}{l}1.220^{* * *} \\
(0.457)\end{array}$ & & $\begin{array}{c}0.956^{* * *} \\
(0.351)\end{array}$ & & $\begin{array}{l}0.939^{* *} \\
(0.377)\end{array}$ \\
\hline $\begin{array}{l}\text { PD Home Country } \\
\times \text { Home Bias }\end{array}$ & & $\begin{array}{l}2.913^{* * *} \\
(1.071)\end{array}$ & & $\begin{array}{c}1.895^{* * *} \\
(0.695)\end{array}$ & & $\begin{array}{c}2.491^{* * *} \\
(0.724)\end{array}$ \\
\hline Stresstest 2011 & $\begin{array}{c}11.64^{* * *} \\
(1.504)\end{array}$ & $\begin{array}{c}10.45^{* * *} \\
(1.179)\end{array}$ & $\begin{array}{c}12.26^{* * *} \\
(1.403)\end{array}$ & $\begin{array}{c}10.92^{* * *} \\
(1.274)\end{array}$ & $\begin{array}{c}12.07^{* * *} \\
(1.468)\end{array}$ & $\begin{array}{c}10.19^{* * *} \\
(1.470)\end{array}$ \\
\hline Stresstest 2014 & $\begin{array}{c}12.23^{* * *} \\
(1.172)\end{array}$ & $\begin{array}{c}10.82^{* * *} \\
(1.037)\end{array}$ & $\begin{array}{c}12.95^{* * *} \\
(0.988)\end{array}$ & $\begin{array}{c}11.51^{* * *} \\
(0.947)\end{array}$ & $\begin{array}{c}12.73^{* * *} \\
(1.062)\end{array}$ & $\begin{array}{c}10.87^{* * *} \\
(1.083)\end{array}$ \\
\hline Equity $(j=1)$ & $\begin{array}{c}-3.452^{* * *} \\
(0.987)\end{array}$ & $\begin{array}{c}-4.218^{* * *} \\
(1.376)\end{array}$ & $\begin{array}{c}-3.833^{* * *} \\
(1.022)\end{array}$ & $\begin{array}{c}-4.320^{* * *} \\
(1.285)\end{array}$ & $\begin{array}{c}-4.133^{* * *} \\
(0.996)\end{array}$ & $\begin{array}{c}-4.777^{* * *} \\
(1.185)\end{array}$ \\
\hline Size & $\begin{array}{c}-3.895^{* * *} \\
(1.049)\end{array}$ & $\begin{array}{c}-3.790^{* * *} \\
(1.269)\end{array}$ & $\begin{array}{c}-1.764^{* *} \\
(0.819)\end{array}$ & $\begin{array}{l}-1.395^{*} \\
(0.717)\end{array}$ & $\begin{array}{c}-1.237^{* * *} \\
(0.433)\end{array}$ & $\begin{array}{c}-1.051^{* *} \\
(0.416)\end{array}$ \\
\hline ROA & $\begin{array}{l}-1.129 \\
(0.693)\end{array}$ & $\begin{array}{c}-1.523^{* *} \\
(0.664)\end{array}$ & $\begin{array}{c}-1.383^{* *} \\
(0.702)\end{array}$ & $\begin{array}{c}-1.730^{* *} \\
(0.858)\end{array}$ & $\begin{array}{c}-1.691^{* *} \\
(0.775)\end{array}$ & $\begin{array}{c}-2.235^{* *} \\
(1.071)\end{array}$ \\
\hline Constant & $\begin{array}{c}-16.16^{* * *} \\
(0.813)\end{array}$ & $\begin{array}{c}-16.03^{* * *} \\
(0.864)\end{array}$ & $\begin{array}{c}-15.73^{* * *} \\
(0.701)\end{array}$ & $\begin{array}{c}-14.87^{* * *} \\
(0.796)\end{array}$ & $\begin{array}{c}-15.02^{* * *} \\
(0.754)\end{array}$ & $\begin{array}{c}-13.82^{* * *} \\
(0.857)\end{array}$ \\
\hline Observations & 261 & 261 & 261 & 261 & 261 & 261 \\
\hline Pseudo $R^{2}$ & 0.483 & 0.596 & 0.485 & 0.560 & 0.506 & 0.579 \\
\hline$\chi^{2}$ & 2406.5 & 1492.2 & 6398.5 & 1697.3 & 2010.8 & 2113.7 \\
\hline Prob $>\chi^{2}$ & 0 & $6.67 \mathrm{e}-317$ & 0 & 0 & 0 & 0 \\
\hline
\end{tabular}

Standard errors in parentheses

${ }^{*} p<0.1,{ }^{* *} p<0.05,{ }^{* * *} p<0.01$ 
Table 10: Marginal Effects $(j=1)$

\begin{tabular}{|c|c|c|c|c|c|c|}
\hline \multirow{3}{*}{ Home Bias } & \multirow{2}{*}{\multicolumn{2}{|c|}{$\begin{array}{cc}(1) & (2) \\
\text { CET1 ratio }<5.5 \%\end{array}$}} & \multirow{2}{*}{\multicolumn{2}{|c|}{$\begin{array}{c}(3) \\
\text { CET1 ratio }<6.0 \%\end{array}$}} & \multirow{2}{*}{\multicolumn{2}{|c|}{$\begin{array}{cc}(5) & (6) \\
\text { CET1 ratio }<6.5 \%\end{array}$}} \\
\hline & & & & & & \\
\hline & $\begin{array}{c}-0.00119 \\
(0.0113)\end{array}$ & $\begin{array}{l}-0.0645 \\
(0.0687)\end{array}$ & $\begin{array}{l}0.00574 \\
(0.0131)\end{array}$ & $\begin{array}{c}-0.000713 \\
(0.0206)\end{array}$ & $\begin{array}{l}0.00645 \\
(0.0140)\end{array}$ & $\begin{array}{l}-0.0210 \\
(0.0177)\end{array}$ \\
\hline PD Home Country & & $\begin{array}{l}0.0625^{* *} \\
(0.0251)\end{array}$ & & $\begin{array}{l}0.0655^{* *} \\
(0.0270)\end{array}$ & & $\begin{array}{l}0.0634^{* *} \\
(0.0296)\end{array}$ \\
\hline Stresstest 2011 & $\begin{array}{c}0.980^{* * *} \\
(0.261)\end{array}$ & $\begin{array}{c}0.673^{* * *} \\
(0.166)\end{array}$ & $\begin{array}{c}1.111^{* * *} \\
(0.277)\end{array}$ & $\begin{array}{c}0.825^{* * *} \\
(0.186)\end{array}$ & $\begin{array}{c}1.142^{* * *} \\
(0.290)\end{array}$ & $\begin{array}{c}0.809^{* * *} \\
(0.201)\end{array}$ \\
\hline Stresstest 2014 & $\begin{array}{c}1.030^{* * *} \\
(0.245)\end{array}$ & $\begin{array}{c}0.696^{* * *} \\
(0.167)\end{array}$ & $\begin{array}{c}1.174^{* * *} \\
(0.257)\end{array}$ & $\begin{array}{c}0.870^{* * *} \\
(0.179)\end{array}$ & $\begin{array}{c}1.205^{* * *} \\
(0.267)\end{array}$ & $\begin{array}{c}0.863^{* * *} \\
(0.185)\end{array}$ \\
\hline Equity $(j=1)$ & $\begin{array}{l}-0.291^{* * *} \\
(0.0460)\end{array}$ & $\begin{array}{c}-0.271^{* * *} \\
(0.0588)\end{array}$ & $\begin{array}{c}-0.347^{* * *} \\
(0.0550)\end{array}$ & $\begin{array}{c}-0.326^{* * *} \\
(0.0724)\end{array}$ & $\begin{array}{l}-0.391^{* * *} \\
(0.0523)\end{array}$ & $\begin{array}{c}-0.379^{* * *} \\
(0.0685)\end{array}$ \\
\hline Size & $\begin{array}{c}-0.328^{* * *} \\
(0.0858)\end{array}$ & $\begin{array}{c}-0.244^{* * *} \\
(0.0794)\end{array}$ & $\begin{array}{l}-0.160^{* *} \\
(0.0732)\end{array}$ & $\begin{array}{l}-0.105^{* *} \\
(0.0518)\end{array}$ & $\begin{array}{l}-0.117^{* * *} \\
(0.0399)\end{array}$ & $\begin{array}{c}-0.0834^{* * *} \\
(0.0306)\end{array}$ \\
\hline ROA & $\begin{array}{l}-0.0951^{*} \\
(0.0540)\end{array}$ & $\begin{array}{c}-0.0979^{* *} \\
(0.0468)\end{array}$ & $\begin{array}{l}-0.125^{* *} \\
(0.0568)\end{array}$ & $\begin{array}{l}-0.131^{* *} \\
(0.0667)\end{array}$ & $\begin{array}{l}-0.160^{* *} \\
(0.0628)\end{array}$ & $\begin{array}{l}-0.177^{* *} \\
(0.0824)\end{array}$ \\
\hline Observations & 261 & 261 & 261 & 261 & 261 & 261 \\
\hline
\end{tabular}

Standard errors in parentheses

${ }^{*} p<0.1,{ }^{* *} p<0.05,{ }^{* * *} p<0.01$ 
Table 11: Propensity to Default and Home Bias - Imputed Risk Weights $(j=2)$

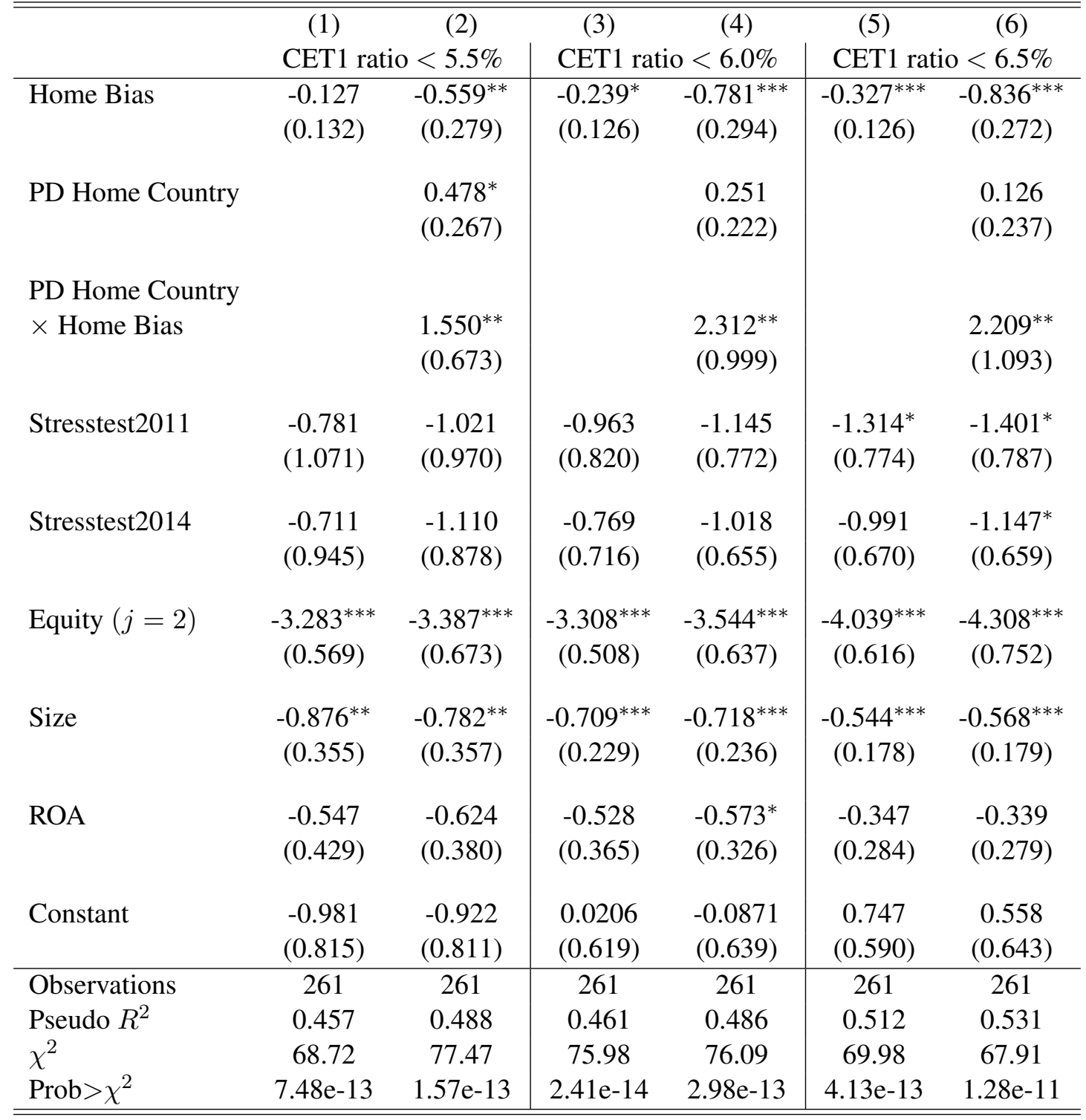

Standard errors in parentheses

${ }^{*} p<0.1,{ }^{* *} p<0.05,{ }^{* * *} p<0.01$ 
Table 12: Marginal Effects $(j=2)$

\begin{tabular}{|c|c|c|c|c|c|c|}
\hline \multirow{3}{*}{ Home Bias } & (1) & (2) & (3) & (4) & $\overline{~(5)}$ & (6) \\
\hline & \multicolumn{2}{|c|}{ CET1 ratio $<5.5 \%$} & \multicolumn{2}{|c|}{ CET1 ratio $<6.0 \%$} & \multicolumn{2}{|c|}{ CET1 ratio $<6.5 \%$} \\
\hline & $\begin{array}{l}-0.0143 \\
(0.0150)\end{array}$ & $\begin{array}{l}-0.0483^{*} \\
(0.0280)\end{array}$ & $\begin{array}{l}-0.0284^{*} \\
(0.0149)\end{array}$ & $\begin{array}{c}-0.0961^{* * *} \\
(0.0311)\end{array}$ & $\begin{array}{c}-0.0350^{* * *} \\
(0.0132)\end{array}$ & $\begin{array}{c}-0.104^{* * *} \\
(0.0303)\end{array}$ \\
\hline PD Home Country & & $\begin{array}{c}0.0364 \\
(0.0301)\end{array}$ & & $\begin{array}{l}0.00342 \\
(0.0294)\end{array}$ & & $\begin{array}{c}-0.00730 \\
(0.0278)\end{array}$ \\
\hline Stresstest 2011 & $\begin{array}{l}-0.0881 \\
(0.119)\end{array}$ & $\begin{array}{l}-0.108 \\
(0.101)\end{array}$ & $\begin{array}{c}-0.115 \\
(0.0962)\end{array}$ & $\begin{array}{c}-0.130 \\
(0.0877)\end{array}$ & $\begin{array}{l}-0.141^{*} \\
(0.0809)\end{array}$ & $\begin{array}{l}-0.144^{*} \\
(0.0805)\end{array}$ \\
\hline Stresstest 2014 & $\begin{array}{l}-0.0802 \\
(0.105)\end{array}$ & $\begin{array}{c}-0.117 \\
(0.0910)\end{array}$ & $\begin{array}{l}-0.0916 \\
(0.0846)\end{array}$ & $\begin{array}{c}-0.115 \\
(0.0748)\end{array}$ & $\begin{array}{c}-0.106 \\
(0.0719)\end{array}$ & $\begin{array}{l}-0.118^{*} \\
(0.0691)\end{array}$ \\
\hline Equity $(j=2)$ & $\begin{array}{c}-0.370^{* * *} \\
(0.0440)\end{array}$ & $\begin{array}{c}-0.358^{* * *} \\
(0.0512)\end{array}$ & $\begin{array}{c}-0.394^{* * *} \\
(0.0353)\end{array}$ & $\begin{array}{c}-0.402^{* * *} \\
(0.0432)\end{array}$ & $\begin{array}{c}-0.432^{* * *} \\
(0.0318)\end{array}$ & $\begin{array}{c}-0.443^{* * *} \\
(0.0385)\end{array}$ \\
\hline Size & $\begin{array}{c}-0.0988^{* * *} \\
(0.0383)\end{array}$ & $\begin{array}{c}-0.0826^{* *} \\
(0.0367)\end{array}$ & $\begin{array}{c}-0.0844^{* * *} \\
(0.0270)\end{array}$ & $\begin{array}{c}-0.0815^{* * *} \\
(0.0265)\end{array}$ & $\begin{array}{c}-0.0583^{* * *} \\
(0.0190)\end{array}$ & $\begin{array}{c}-0.0585^{* * *} \\
(0.0186)\end{array}$ \\
\hline ROA & $\begin{array}{l}-0.0618 \\
(0.0472)\end{array}$ & $\begin{array}{c}-0.0659 \\
(0.0402)\end{array}$ & $\begin{array}{c}-0.0629 \\
(0.0428)\end{array}$ & $\begin{array}{l}-0.0650^{*} \\
(0.0375)\end{array}$ & $\begin{array}{c}-0.0371 \\
(0.0305)\end{array}$ & $\begin{array}{l}-0.0349 \\
(0.0294)\end{array}$ \\
\hline Observations & 261 & 261 & 261 & 261 & 261 & 261 \\
\hline
\end{tabular}

Standard errors in parentheses

${ }^{*} p<0.1,{ }^{* *} p<0.05,{ }^{* * *} p<0.01$ 
Table 13: Propensity to Default and Home Bias - Imputed Risk Weights and Equity Requirements for EU Sovereign Bonds $(j=3)$

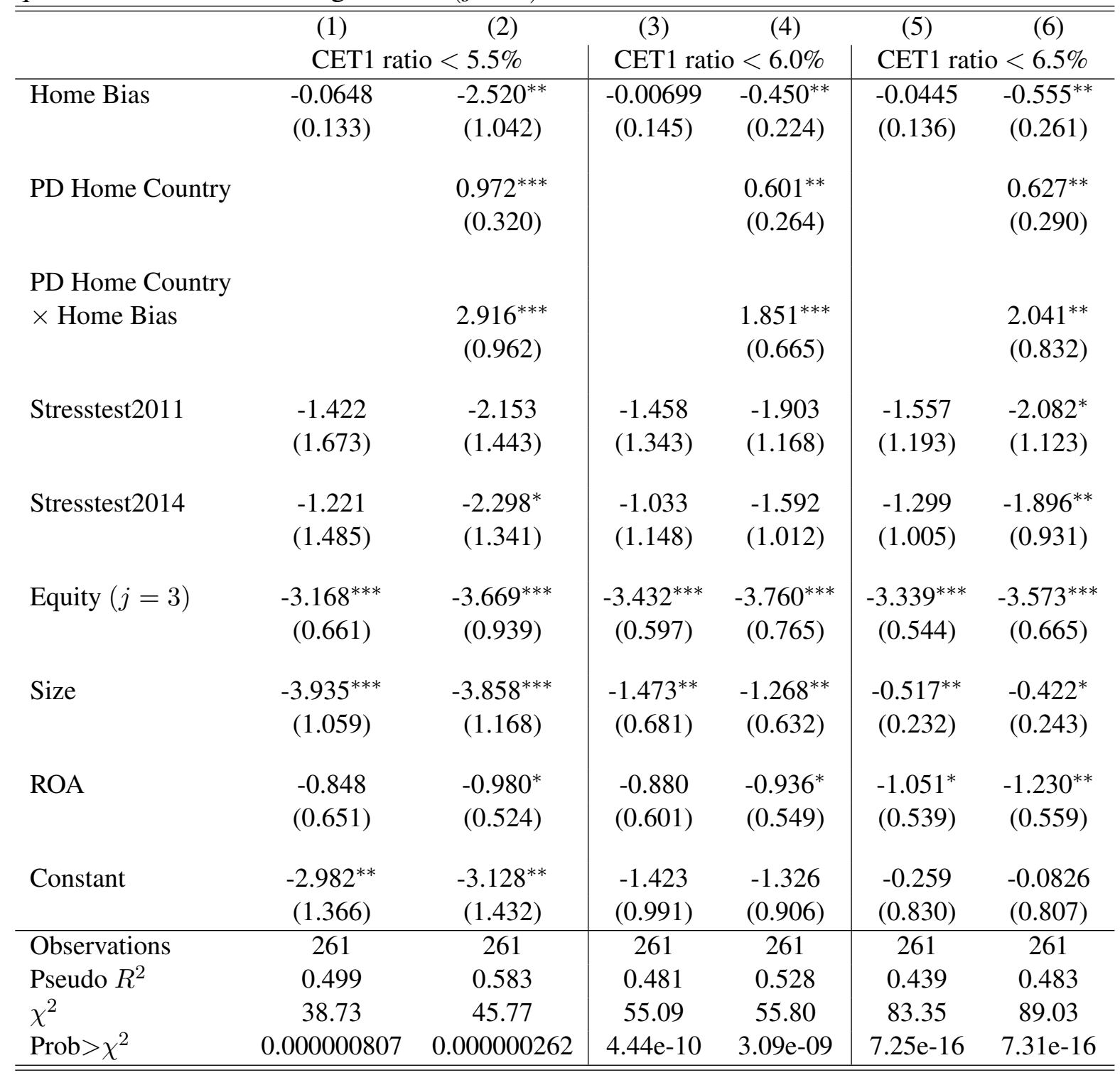

Standard errors in parentheses

${ }^{*} p<0.1,{ }^{* *} p<0.05,{ }^{* * *} p<0.01$ 
Table 14: Marginal Effects $(j=3)$

\begin{tabular}{|c|c|c|c|c|c|c|}
\hline \multirow{3}{*}{ Home Bias } & \multirow{2}{*}{\multicolumn{2}{|c|}{$\begin{array}{cl}(1) & (2) \\
\text { CET1 ratio }< & 5.5 \%\end{array}$}} & \multirow{2}{*}{\multicolumn{2}{|c|}{$\begin{array}{cc}(3) & (4) \\
\text { CET1 ratio }<6.0 \%\end{array}$}} & \multirow{2}{*}{\multicolumn{2}{|c|}{$\begin{array}{c}(5) \\
\text { CET1 ratio }<6.5 \%\end{array}$}} \\
\hline & & & & & & \\
\hline & $\begin{array}{l}-0.00535 \\
(0.0111)\end{array}$ & $\begin{array}{l}-0.0968 \\
(0.0620)\end{array}$ & $\begin{array}{c}-0.000683 \\
(0.0141)\end{array}$ & $\begin{array}{c}-0.00970 \\
(0.0173)\end{array}$ & $\begin{array}{c}-0.00528 \\
(0.0162)\end{array}$ & $\begin{array}{r}-0.0586^{* *} \\
(0.0273)\end{array}$ \\
\hline PD Home Country & & $\begin{array}{l}0.0492^{* *} \\
(0.0205)\end{array}$ & & $\begin{array}{l}0.0455^{*} \\
(0.0247)\end{array}$ & & $\begin{array}{c}0.0459 \\
(0.0334)\end{array}$ \\
\hline Stresstest 2011 & $\begin{array}{l}-0.117 \\
(0.134)\end{array}$ & $\begin{array}{c}-0.146 \\
(0.0967)\end{array}$ & $\begin{array}{l}-0.142 \\
(0.127)\end{array}$ & $\begin{array}{l}-0.167^{*} \\
(0.100)\end{array}$ & $\begin{array}{l}-0.184 \\
(0.135)\end{array}$ & $\begin{array}{l}-0.225^{*} \\
(0.116)\end{array}$ \\
\hline Stresstest 2014 & $\begin{array}{l}-0.101 \\
(0.118)\end{array}$ & $\begin{array}{l}-0.156^{*} \\
(0.0887)\end{array}$ & $\begin{array}{l}-0.101 \\
(0.108)\end{array}$ & $\begin{array}{c}-0.139 \\
(0.0850)\end{array}$ & $\begin{array}{l}-0.154 \\
(0.114)\end{array}$ & $\begin{array}{l}-0.205^{* *} \\
(0.0955)\end{array}$ \\
\hline Equity $(j=3)$ & $\begin{array}{c}-0.262^{* * *} \\
(0.0300)\end{array}$ & $\begin{array}{c}-0.249^{* * *} \\
(0.0378)\end{array}$ & $\begin{array}{c}-0.335^{* * *} \\
(0.0384)\end{array}$ & $\begin{array}{c}-0.329^{* * *} \\
(0.0496)\end{array}$ & $\begin{array}{c}-0.396^{* * *} \\
(0.0435)\end{array}$ & $\begin{array}{r}-0.387^{* * *} \\
(0.0543)\end{array}$ \\
\hline Size & $\begin{array}{c}-0.325^{* * *} \\
(0.0795)\end{array}$ & $\begin{array}{c}-0.261^{* * *} \\
(0.0761)\end{array}$ & $\begin{array}{l}-0.144^{* *} \\
(0.0618)\end{array}$ & $\begin{array}{l}-0.111^{* *} \\
(0.0520)\end{array}$ & $\begin{array}{c}-0.0612^{* *} \\
(0.0275)\end{array}$ & $\begin{array}{l}-0.0456^{*} \\
(0.0266)\end{array}$ \\
\hline ROA & $\begin{array}{l}-0.0700 \\
(0.0510)\end{array}$ & $\begin{array}{l}-0.0664^{*} \\
(0.0376)\end{array}$ & $\begin{array}{l}-0.0859 \\
(0.0559)\end{array}$ & $\begin{array}{c}-0.0820^{*} \\
(0.0478)\end{array}$ & $\begin{array}{l}-0.125^{* *} \\
(0.0592)\end{array}$ & $\begin{array}{l}-0.133^{* *} \\
(0.0579)\end{array}$ \\
\hline Observations & 261 & 261 & 261 & 261 & 261 & 261 \\
\hline
\end{tabular}



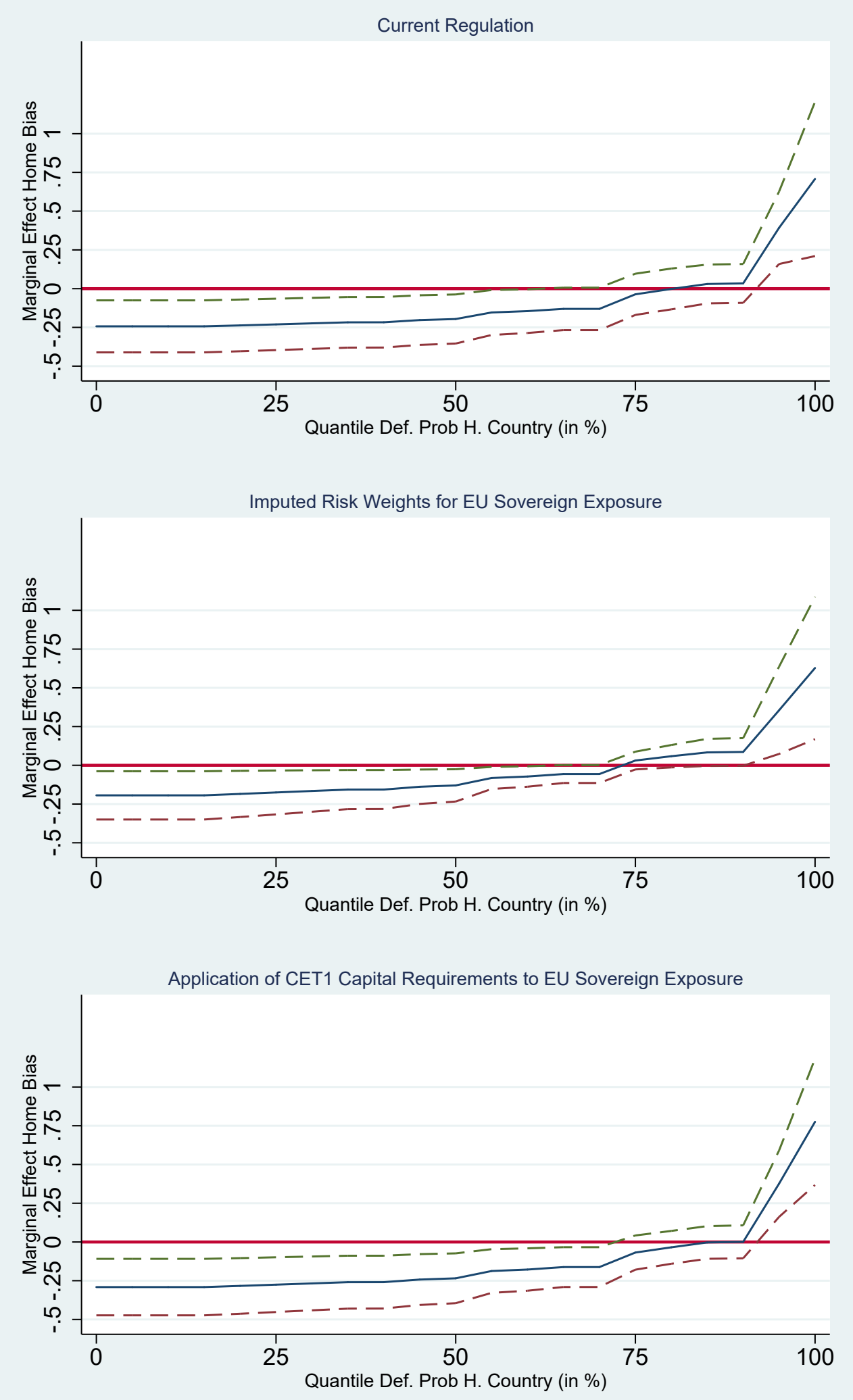

Figure 4: Conditional Marginal Effects of the Home Bias at 5.5\%-threshold, set all other variables to their mean (Dashed lines $95 \%$ conf. interval) 

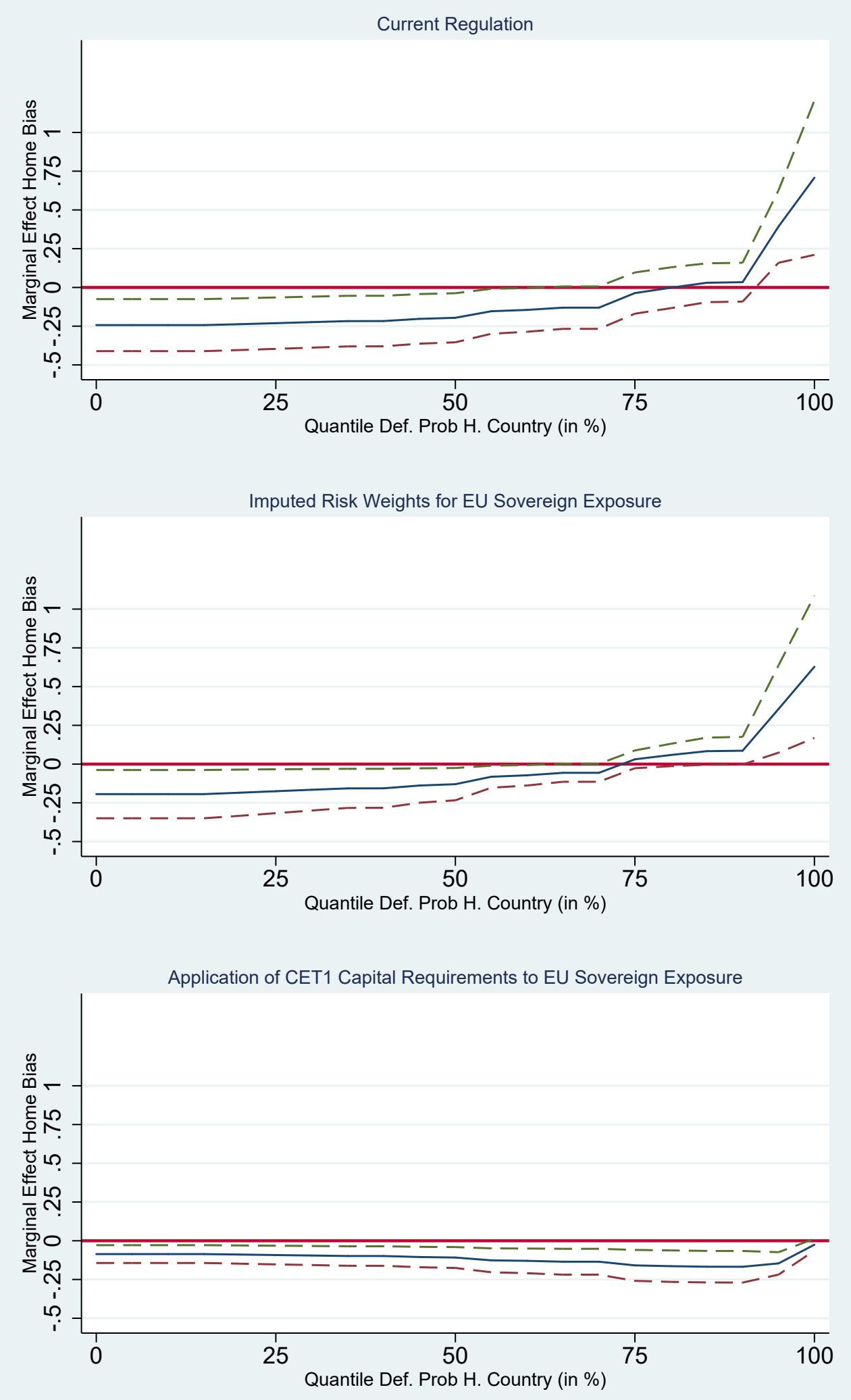

Figure 5: Conditional Marginal Effects of the Home Bias at 5.5\% Threshold assuming $25 \%$ Add. Equity, set all other variables to their mean (Dashed lines $95 \%$ conf. interval) 


\section{References}

Acharya, V., Drechsler, I., \& Schnabl, P. (2014). A pyrrhic victory? bank bailouts and sovereign credit risk. The Journal of Finance, 69(6), 2689-2739.

Acharya, V., \& Steffen, S. (2015). The "greatest" carry trade ever? understanding eurozone bank risks. Journal of Financial Economics, Vol. 115(2), 15-236.

Altavilla, C., Pagano, M., \& Simonelli, S. (2017). Bank exposures and sovereign stress transmission. Review of Finance, Vol. 21(6), 2103-2139.

Andreeva, D., \& Vlassopoulos, T. (2019). Home bias in bank sovereign bond purchases and the bank-sovereign nexus. International Journal of Central Banking, Vol-15(1), 157-197.

Baldacci, E., \& Kumar, M. (2010). Fiscal deficits, public debt, and sovereign bond yields. ECB Working Paper Series, No. 10/184.

BCBS. (2006). International convergence of capital measurement and capital standards a revised framework comprehensive version.

BCBS. (2017a). Basel iii: Finalising post-crisis reforms.

BCBS. (2017b). The regulatory treatment of sovereign exposures (Tech. Rep.). Basel Committee on Banking Supervision.

Beck, R., Jakubik, P., \& Piloiu, A. (2013). Non-performing loans - what matters in addition to the economic cycle? ECB Working Paper Series, No. 1515.

Brunnermeier, M., Garciano, L., Lane, P., Pagano, M., Reis, R., Santos, T., ... Vajanos, D. (2016). The sovereign-bank diabolic loop and esbies. American Economic Review Papers and Proceedings, Vol. 106(5), 508-512.

Cameron, A. C., \& Trivedi, P. K. (2005). Microeconometrics: methods and applications. New York: Cambridge University Press.

Crotty, J. (2009). Structural causes of the global financial crisis: a critical assessment of the new financial architecture. Cambridge Journal of Economics, Vol. 67(3), 563-580.

EBA. (2011). European banking authority 2011 eu-wide stress test aggregated report.

EBA. (2014). Results of 2014 eu-wide stress test.

EBA. (2016). 2016 eu-wide stress test.

European Union. (2013). Regulation (eu) no 575/2013 of the european parliament and of the council of 26 june 2013 on prudential requirements for credit institutions and investment firms and amending regulation.

Freixas, X., Giannini, C., Hoggarth, G., \& Soussa, F. (2000). The lender of last resort: what we learned since bagehot? Journal of Financial Services Research, Vol. 18(1), 63-87.

French, K. R., \& Poterba, J. M. (1991). Investor diversification and international equity 
markets. American Economic Review, Vol. 81(2), 222-226.

Horváth, B. L., Huizinga, H., \& Ioannidou, V. (2015). Determinants and valuation effects of the home bias in european banks' sovereign debt portfolios. CEPR Discussion Paper Series, No. 10661.

Hull, J. C. (2017). Options, futures, and other derivatives. London: Pearson Education, 9th Edition.

Jensen, M. C., \& Meckling, W. H. (1976). Theory of the firm: managerial behavior, agency costs and ownership structure. Journal of Financial Economics, Vol. 3(4), 305-360.

Koehn, M., \& Santomero, A. M. (1980). Regulation of bank capital and portfolio risk. Journal of Finance, Vol. 50(6), 1235-1244.

Li, J., \& Zinna, G. (2018). How much of bank credit risk is sovereign risk? evidence from europe. Journal of Money, Credit and Banking, Vol. 35(5), 1225-1269.

Reinhart, C. S., Reinhart, V. R., \& Rogoff, K. S. (2012). Public debt overhangs: Advanced-economy episodes since 1800. Journal of Economic Perspectives, Vol. 26(3), 69-86.

Schnabel, I., \& Schüwer, U. (2016). What drives the relationship between bank and sovereign credit risk? Arbeitspapiere, Sachverständigenrat zur Begutachtung der gesamtwirtschaftlichen Entwicklung, No. 07/2016.

Szmaragd, C., Clarke, P., \& Steele, F. (2013). Subject specific and population average models for binary longitudinal data: a tutorial. Longitudinal and life course studies, Vol. 42(2), 147-165.

Thornton, H. (1802). An enquiry into the nature and effects of the paper credit of great britain. London: Printed for J. Hatchard and Messrs. F. and C. Rivington.

Uhlig, H. (2014). Sovereign default risk and banks in a monetary union. German Economic Review, Vol. 15(1), 23-41.

Yawitz, B. (1977). An model of interest rate differentials and different default recoveries. Journal of Financial and Quantitative Analysis, Vol. 12(3), 481-490. 